\title{
İstanbul Üniversitesi Sosyoloji Dergisi
}

Başvuru: 02 Mart 2020

Revizyon Talebi: 12 Haziran 2020

Son Revizyon: 15 Haziran 2020

Kabul: 17 Haziran 2020

\section{Biyoiktidar, Beslenme ve Annelik: Emzirmenin Kültürel ve Politik Görünümleri}

\author{
Meral Timurturkan ${ }^{1}$ (])
}

Öz

Bu çalışma; anneliğin ve bebek beslenmesinin, kadın bedeninin sosyo-politik süreçlerin pekiştirilmesinin ve ataerkil sistemin sürekliliğinin sağlamasının zemini olarak çeşitli düzenlemelere ve söylemlere nasıl açık hale geldiğini emzirme örneği üzerinden tartş̧mayı amaçlamaktadır. Günümüzde doğal beslenme, ekolojik yaşam, teknolojik ve tıbbi bilgideki gelişmelerin etkisiyle beslenme ve beden sosyopolitik sürecin ve bu alandaki söylemlerin odağına yerleșmiştir. Bu bağlamda bebek beslenmesi ve emzirme bir yandan doğal, sağlıklı ve katkısız özellikleriyle yeniden önemli hale gelirken, diğer yandan bu özelliklerine vurgu yapılarak yeni piyasa ve tüketim sürecinin merkezine çekilmekte, ticarileşmekte ve piyasa ilişkileri içinde metalaşmaktadır. Böylelikle anne sütü, hazır mamaların kullanımı ve emzirme tartş̧maları üzerinden annelik normatif olarak inşa edilmekte ve kadın bedeni denetime açık hale getirilmektedir. Çalışma buradan hareketle, annelik, emzirmeye ve bebek beslenmesine ilişkin konuları, beden üzerinden işleyen mikro iktidar ilişkileri, biyopolitika ve tbbileştirme kavramları üzerinden tartş̧acaktı. Bu bağlamda çalışmanın temel argümanı; toplumsal yapılardaki dönüşümler ve feminist çalışmaların tüm kazanımlarına rağmen; annelik ve bebek beslenmesine ilişkin oluşturulan biyo-politik, kültürel ve thbbi söylemler aracilığıyla anneliğe ilişkin süreçlerin disipline edildiği ve ahlaki olarak inşa edildiğidir.

Anahtar Kelimeler: Beslenme • Beden • Emzirme • Annelik • Biyoiktidar • Sağlık

Biopower, Nutrition, and Motherhood: The Cultural and Political Appearances of Breastfeeding Abstract

This study aims to discuss how motherhood, infant nutrition, and the female body have become open to various regulations and discourses using the case of breastfeeding as the basis for reinforcing socio-political processes and ensuring the continuity of the patriarchal system. Today, nutrition and the body have become the focus of socio-political processes and discourses on these subjects with effects on the developments in natural diet, ecological life, and technological and medical knowledge. In this context, while infant nutrition with healthy and additive-free features on one hand has become important again, on the other hand it has been drawn into the center of new market and consumption processes by emphasizing these features and has been commercialized and commoditized within market relations. In this way, motherhood is being constructed normatively, and the female body has become open to supervision through discussions about breastfeeding, breast milk, and infant formula usage. From this point of view, the study will discuss issues regarding motherhood, breastfeeding, and infant nutrition in terms of the micropower relations that have control over the body as well as the concepts of biopolitics and medicalization. In this regard, the study's main argument is that the processes concerning motherhood have been morally disciplined and constructed through the biopolitical, cultural, and medical discourses generated about motherhood and infant nutrition, despite transformations in social structures and the struggles of feminist efforts.

Keywords: Nutrition • Body $\bullet$ Breastfeeding $\bullet$ Motherhood $\bullet$ Biopower $\bullet$ Health

1 Meral Timurturkan (Dr. Öğr. Üyesi), Burdur Mehmet Akif Ersoy Üniversitesi, Fen-Edebiyat Fakültesi Sosyoloji Bölümü, Burdur. Eposta: mtimurturkan@mehmetakif.edu.tr ORCID: 0000-0002-1505-5544

Att: Timurturkan, M. (2020). Biyoiktidar, beslenme ve annelik: emzirmenin kültürel ve politik görünümleri. ístanbul Üniversitesi Sosyoloji Dergisi, 40, 219-248. https://doi.org/10.26650/SJ.2020.40.1.0034 


\section{Extended Summary}

The main purpose of this study is to discuss how the female body, daily relations, and motherhood experiences are disciplined and controlled through medical, political, and cultural discourses regarding motherhood and infant nutrition based on the literature, despite the transformations in social structures, all the achievements of technological developments, and feminist efforts. The female body and motherhood turn into an area of joint intervention for all political systems by way of infant nutrition and breastfeeding, which are normatively regulated under the influence of political, medical, and cultural discourses, By referencing primary sources in the literature in the context of today's societies and by citing previous societies, this study discusses the discourses on womanhood and motherhood, which are an area of joint intervention for the social structures that have changed in the process of history in terms of nutrition, breastfeeding, and infant formula. In this regard, one important point to be emphasized here is that breastfeeding is an important alternative to the commercialized nutrition industry that poses health risks. Without ignoring the struggles of the breastfeeding movement and its great achievements, discuss how motherhood has been drawn into managerial and commercial relationships through nutrition and breastfeeding also is important.

Motherhood and infant nutrition, which are at the center of the discourses of different institutions, have become subject to several regulations and discussions. As each society has its own nutrition culture and motherhood ideology, having cultural differences regarding breastfeeding and infant nutrition is also possible. These differences are formed and shaped through religious, moral, social, economic, medical, and political meanings. As Blum stated (1993, p. 291), breastfeeding represents both the cultural and natural mother and is socially constructed by the discursive framework of discourses on biology. When examining the cultural and political experiences of various societies from past to present, motherhood as well as its immanent processes and situations are seen to have been constructed as important social issues and to have been subjected to several powerful discourses. The processes of pregnancy, childbearing, nutrition, and childcare are constructed by way of medicine, culture, economics, and politics by being incorporated into the normative order of gender.

With the transformation of the "natural," "good," "intense," and "ideal" motherhood ideologies into the dominant motherhood ideologies during the late modern period, women's daily activities have again been reconstructed by transforming the caring, feeding, and nurturing of infants into a basic social issue, due to infant nutrition having become an important political issue that is included in public health discourses and to having significantly profitable returns by becoming industrialized. This has also been transformed into a subject governed by medical discourses. In this process, the medical and cultural meanings of breast milk have been transformed, with breast milk being evaluated as a commodity independent from the female body. In addition to being bought, sold, and 
subjected to an exchange process, breastfeeding and breast milk are discussed through biopolitics and public health and are considered as issues that various volunteer organizations fight for. These groups, formed of women and representing an activist movement advocating breastfeeding (lactivism), have put up a fight in the political and social arenas by supporting the idea of "breast is best" as a reaction to capitalizing on infant nutrition and its healththreatening aspects (Jung, 2015). The struggles these groups have initiated and the campaigns they have conducted since World War II can also be said to have caused conflicting internal discourses to emerge on different axes. The conducted breastfeeding campaigns, infant formula usage, public health education, and legal regulations about breastfeeding (especially providing breaks for working mothers to breastfeed), and establishing breast milk banks are some subjects that have come up for discussion. Breastfeeding, discourses on which occur at the center of political debates and are constructed in integration with various technological and micropower discourses, is subjected to the power relation that Foucault (1993) refers to as biopower. By containing the power of a discipline that targets the human body as an object to be manipulated and trained, biopower is a policy of anatomy that gives women exact and specific advice on how breastfeeding techniques are to be performed. The fact that infant nutrition is not only the mother's duty but has also become the business of governments, health institutions, industries, and the wider society is an issue that has been discussed in this context (Marshall et. al. 2007). By referencing the three different ideologies, Rothman's (2000) analysis about how motherhood is constructed socially and how the female body is subjected to a series of interventions offers important insights on this point. In cooperation with each other, the three structures Rothman defined as the patriarchal, technological, and capitalist ideologies determine the positions women have within society and subject them to power relations by interfering with women's bodies and daily lives. While patriarchy points to the dominance men have over women's bodies, sexuality, roles, and duty in the reproduction process, technology implies the direct control over women's bodies through medical interventions. The medical institution comes into prominence in the relationship between body and technology. The body is seen as a machine and is subject to medical intervention. With motherhood in particular, interfering in the female body is a possibility, and issues such as parity, pregnancy, childbirth, and breastfeeding are subjected to biopolitical discourse by turning these into medical issues. According to Rothman, capitalism reproduces gender relations with the help of patriarchal ideology and technology in a way that will ensure the continuation of its own system and maximize its profit within the relations of production and consumption. In cooperation with one another, these three ideologies constitute the hierarchical power structures in society and can determine the meanings social events have. Accordingly, these three ideologies allow us to understand why breastfeeding and the female body are at the center of the biopolitics, medical power, and other macro- and micro-power structures (i.e., other social institutions, governments, and organizations operating on a micro scale, groups, trade companies) that regulate daily life. This is because 
biopower reorganizes the power relations that affect gender relations with the help of these three ideologies Rothman has mentioned and also organizes women's bodies and their daily activities by defining breastfeeding as the exclusive responsibility of women.

Having discourses that state breastfeeding to be an important element of natural motherhood and others that transform all product services, processes, and natural situations regarding motherhood into a consumption area by integrating them into capitalism indicates that these different discourses are in conflict with each other. Because convenience-food products and infant formulas have an important market share nowadays, breastfeeding has also been integrated into the motherhood ideology as a natural, instinctual behavior and occupies a central place in public health discourses by being placed into the neoliberal risk culture. When this subject is evaluated from the Foucauldian perspective, govermentality of the process and subjecting the female body to a set of surveillance and power strategies are for ensuring the guarantee of healthy generations. For instance, when a mother decides to feed her baby with formula, the result may occur where she is accused of being an insufficient mother who puts herself, needs, choices, and comfort above her baby's well-being (Murphy, 1999, p. 187). While discussions carried out in this context come critically close to the global capitalist aspects on infant formula and nutrition, they also underline that having discourses that evaluate breastfeeding as the only alternative can create moral pressure for women. In particular, the dominant point of view where breastfeeding is the basic component of being a "good" and "ideal" mother, as well as the fact that breastfeeding is represented as the only choice for infant nutrition, may result in restrictions and pressures on women who do not or cannot breastfeed. This fact is also discussed in this context.

Different studies have opened discussions on the effects social dynamics have had, putting forth that good motherhood is evaluated in terms of infant nutrition and bodily performance (Marshall et al. 2007). As a healthy option for babies, breastfeeding has been argued as a normative obligation, with discussions found on the moral pressure on women (Murphy, 1999; 2000). Breastfeeding for women is generally seen as equivalent to good motherhood when the baby looks healthy and happy. On the other hand, if a baby is breastfed frequently but doesn't gain weight or is uneasy, a mother can be seen as inadequate or unsuccessful (Marshall et al. 2007). As a matter of fact, the differences (i.e., variables of subjective capacities, race, class, gender) peculiar to women are anonymized by ignoring them, and their emotions and actions are anonymized by transforming them into political and moral issues. Excessively emphasizing that breastfeeding is an important indicator of being a natural, healthy, reliable and "good" mother in terms of infant nutrition allows the processes related to breastfeeding to be drawn into consumer relations, and this situation creates a pressure on the women who do not or cannot breastfeed. 


\section{Biyoiktidar, Beslenme ve Annelik: Emzirmenin Kültürel ve Politik Görünümleri}

Bebek beslenmesinde önemli bir süreç olan emzirme, biyolojik ve psikolojik bir durum olmanın ötesine geçerek, sosyo-kültürel dinamikler tarafindan yönetilen ve inşa edilen bir olguya dönüşmüştür. Farklı kültürler ve dönemlerde farklı kadınlık ve annelik formları olduğu gibi (Forcey, 1994; Glenn, 1994; Moore, 2003), bebek beslenmesine ilişkin de farklı ahlâki ve toplumsal tanımlamalar vardır. Toplumsal cinsiyet kimliğinin önemli bir yönünü oluşturan annelik kimliği ve ona içkin olan süreçler kültürel pratiklerin odağında yönetilen ve yönlendirilen bir meseleye dönüşmüştür (Allan, 2004; Rothman, 1994; Silva, 2003). Nitekim bunun en somut göstergesi bir kadının toplumsal statüsünün annelik rolünü ne kadar iyi yerine getirdiği üzerinden tanımlanması ve farklı dönemlerde bu durumun hukuki ve politik bir mesele olarak ele alınmasıdır (Badinter, 2011; Trevino, 2010). Geç modern dönemde "doğal", "iyi”, "yoğun", "ideal” annelik ideolojilerinin egemen annelik ideolojisine dönüşmesi ile birlikte, bebeğin bakımı, beslenmesi ve büyütülmesi temel bir toplumsal meseleye dönüştürülerek, kadınların gündelik faaliyetleri yeniden inşa edilmektedir. Anneliğin hem sembolik hem de biyolojik anlamda önemli bir göstereni olarak kabul edilen emzirme ise, sadece bir davranış veya bir beslenme biçimi olarak ele alınmamakta, aynı zamanda kültürel, tıbbı ve politik söylemlerin odağında şekillendirilen bir mesele olarak da tartışılmaktadır.

Bebek beslenmesinin ve emzirmenin tarihini ve kültürel dinamiklerini anlayabilmek için, biyolojiyi, araştırmaları, politikaları, kaynakları, potansiyel sorunları, tedavileri ve çevresel destekleri de iyi anlamak ve kavramak önemlidir (Vancour, 2010, s. 142). Çünkü bebek beslenmesi sadece toplumsal ve kültürel yönü olan bir mesele olmayıp, aynı zamanda endüstrileşerek önemli kâr getirisi olan bir alana, halk sağlı̆̆1 söylemlerine dahil edilen politik bir meseleye ve tıbbı söylemin yönettiği bir konuya da dönüştürülmüştür. $\mathrm{Bu}$ süreçte anne sütünün tıbbi ve kültürel anlamları da dönüşüme uğramakta ve anne sütü kadının bedeninden bağımsız bir meta olarak da ele alınmaktadır. Alınıp satılabilen, mübadeleye konu olan halk sağlığının, biyo-politikanın gündeminde de yer alan emzirme ve anne sütü, çeşitli gönüllü kuruluşların üzerine mücadele yürüttüğü bir mesele olarak da ele alınmaktadır. Emzirme savunuculuğunun aktivist yönünü temsil eden (lactivism) ve çoğunlukla kadınlardan oluşan bu gruplar, bebek beslenmesinin kapitalistleşen ve sağlığı tehdit eden boyutuna bir tepki olarak "meme en iyisi" fikrini merkeze alarak politik ve toplumsal arenada mücadele yürütmüşlerdir (Jung, 2015).

Bir yandan emzirmenin özellikle gelişmiş ülkelerde halk sağlığı politikalarına dahil edilmesi, sütün formüle edilerek endüstriyel bir metaya dönüşmesi, öte yandan emzirmeyi savunan grupların (La Leche League gibi) İkinci Dünya Savaşından sonra başlattıkları mücadele ve yürüttükleri kampanyalar, farklı eksenlerde birbiri ile çatışan söylemlerin da ortaya çıkmasına kaynaklık ettiği söylenebilir. Çünkü beslenme önemli 
bir halk sağlığı sorunu olarak ele alınırken, bebek beslenmesi başlı başına ayrı bir alan olarak önemsenmekte ve çeşitli düzenlemelere tabi tutulmaktadır. Yürütülen emzirme kampanyaları, halk sağlığı eğitimleri, politik olarak emzirmeye ilişkin yasal düzenlemeler, formül mamaların kullanımı ve pazarlanması, çalışan annelere süt izni hakkı, süt bankalarının kurulması ve etik boyutu bu kapsamda tartışmaya açılan konulardan bazılarıdır. Biyopolitik iktidarın odağında yürütülen ve farklı teknolojik ve mikro iktidarların bütünleşik söylemleri ile inşa edilen emzirme ve ona ilişkin süreçler, sosyolojik olarak önemsenen konular arasında yer almaya başlamıştır (Alianmoghaddam ve ark., 2017; Lee, 2018; Palmer, 2009). Anne sütü bankalarının kurulması, tıbbi söylemin emzirme ve bebek beslenmesi üzerinde ağırlık kazanması, sosyal medya üzerinden ve farklı yöntemlerle satılan anne sütleri ve süt bağışları, Türkiye'de süt bankasının kurulmasına karşı çıkan baskın dini söylem anneliğe ve emzirmeye ilişkin konuların gündeme gelmesini sağlamaktadır. Bu bağlamda yürütülen tartışmalar formül mamaların ve beslenmenin büyüyen küresel kapitalist boyutuna eleştirel yaklaşırken, emzirmeyi alternatifsiz sunan söylemlerin ise kadınlar için ahlaki bir baskı yaratabileceğine dikkat çekmektedir. Özellikle emzirmenin "iyi” ve "ideal" anne olmanın temel bir birleşeni olduğuna yönelik ortaya çıan egemen bakış açısı ve bebek beslenmesinde yegane seçenek olarak sunulmasının, emzir(e)meyen anneler üzerinde yaptırım ve baskıya dönüşebileceği de tartışılmaktadır. Dolayısıyla farklı kurumların söylemlerinin odağında yer alan annelik ve bebek beslenmesi, düzenlemelere ve tartışmalara açık hale gelmektedir. Her toplumun farklı bir beslenme kültürü ve annelik ideolojisi olduğu gibi emzirme ve bebek beslenmesine yönelik kültürel değişkenler de söz konusu olabilmekte, bu değiş̧kenler dini, ahlaki, toplumsal, ekonomik, tıbbi ve politik anlamlarda şekillenerek oluşmaktadır. Blum'un da ifade ettiği (1993, s. 291) gibi emzirme hem kültürel hem de doğal anneyi temsil etmekte ve biyolojik söylemelerin söylemsel çerçeveleri ile toplumsal olarak inşa edilmektedir.

Söz konusu tartışmalardan hareketle bu çalışmanın temel amacı toplumsal yapılardaki dönüşümlere, teknolojik gelişmelere ve feminist çalışmaların tüm kazanımlarına rağmen; annelik ve bebek beslenmesine ilişkin tıbbi, politik ve kültürel söylemler aracıllğıyla, kadının bedeninin, gündelik ilişkilerinin ve annelik deneyiminin nasıl disipline edildiğini ve denetlendiğini literatürden hareketle tartışmaktır. Politik, tıbbi ve kültürel söylemin etkisi altında normatif olarak düzenlenen bebek beslenmesi ve emzirme aracılığıla kadın bedeni ve annelik, tüm toplumsal sistemlerin de ortak müdahale alanına dönüşmektedir. Çalışma bu anlamda literatürde yer alan birincil kaynaklardan hareketle tarihsel süreç içerisinde değişen toplumsal yapıların ortak müdahale zemini olan kadınlık ve dolayısıyla anneliğe ilişkin söylemlerin beslenme, emzirme ve hazır mama üzerinden geçmiş toplumlara referansla günümüz toplumları bağlamında tartışılmasını içermektedir. Burada vurgulanması gereken önemli noktalardan biri de çalışma, emzirmenin ticarileşen ve sağlığı tehdit eden beslenme endüstrisine karşı önemli doğal bir besin olduğunu ve bu konuda önemli kazanımlar elde eden emzirmeyi savunan grupların aktivist çabalarını 
göz ardı etmeden, beslenme ve emzirme dolayımıyla anneliğin yönetimsel, toplumsal ve ticari bir ilişki ağına dahil edilmesini tartışmaktadır.

\section{Emzirmenin Tarihsel ve Kültürel Anlamları}

Anneliğin toplumsal ve kültürel görünümleri çocuk bakımı ve gelişiminde önemli bir süreç olarak kabul edilen emzirme üzerinde de etkili olmuş, anne sütü ve emzirme beslenmenin ötesine geçerek önemli bir sosyal ve politik meseleye dönüştürülmüş̧ür. Tarihsel süreç içinde farklı toplumların ve kültürel pratiklerin emzirmeye bakışı, anne sütünü anlamlandırma biçimi, kadının gögüslerini tanımlama şekli, bebek beslenme yöntemleri farklılık göstermiş ve bu tanımlamalar kadınların gündelik hayat pratiklerine ve toplumsal ilişkilerine yansıyarak, onların sosyal statüsünü belirlemede de etkili olmuştur. Nitekim çeşitli çalışmalar ve antropolojik bulgular bebek beslenmesinde anne sütünün önemini ve aynı zamanda bir halk sağlığı meselesi olduğunu da ortaya koymaktadır (Dykes, 2002; Walks, 2010). Arkeolojik çalışmalar emzirmeye ve bebek beslenmesine ilişkin bulgulara iskelet kalıntıları, diş minesi gibi bedensel süreçlerin yanında, arşivleri ve sanatı da kullanarak ulaşmaktadır. Tarih öncesi dönemlerde emzirmenin kültürel boyutu tam olarak bilinmese de arkeologlar diş minelerine bakarak, çocuğun emzirme süreci ve yemeğe başlama yaşına ilişkin çeşitli veriler elde etmektedir (Walks, 2010, s. 64). Cassidy ve El Tom'un (2015, s. 2) farklı kaynaklardan ve antropologların yaptığı çalışmalardan aktardıklarına göre bir bebeğin ne kadar süre ile ve ne zamana kadar emzirileceğine ilişkin kültürler arası bir fikir birliği bulunmamakta ancak biyo-kültürel kanıtlardan yola çıkılarak bebeklerin iki ve yedi yaşına kadar anne sütü almaya devam ettiği tartışılmaktadır

Geçmişten günümüze farklı kültür ve uygarlıklarda anne sütü, bebek beslenmesinde önemli bir besin kaynağı olarak görülmüş ve emzirme kültürel olarak inşa edilmiştir. Emzirmenin öğütlenerek savunulması çok eski tarihi kaynaklara dayanmakta ve bu kaynaklar aynı zamanda dönemin tıbbi uygulamaları, gündelik hayat pratikleri ve bebek beslenmesine ilişkin çeşitli bilgileri de içermektedir. Dykes'1n (2002, s. 493) aktardığına göre örneğin Milattan önce 16. Yüzyılda yaşadığı düşünülen ve tıbbi çalışmaları olan George Maurice Ebers'in yazdığ1 ve Ebers Papirüsü’ü olarak da bilinen tıp yazması, emzirmeye ilişkin çeşitli bilgi ve öğütleri içeren önemli bir belge olarak kabul edilmektedir. Öte yandan en eski yazılı kanun olarak bilinen Hammurabi kanunları emzirmeye ve süt anneliğe ilişkin ilk yasal düzenlemelerin yapıldığı hukuki yazit olarak da kabul edilmektedir (Trevino, 2010, s. 491). Eski Hindistan'da, Milattan önce iki bin yıldaki Ayurveda metni doğum sonrası ilk yılın sonuna kadar bebekler için tek gıda olarak anne sütünü reçete ederek emzirmenin önemini vurgulamaktaydı. Milattan önce. 4. yüzyılda Sparta'da kraliyet kararnamesi ile bebeklerin emzirilmesi gerektiği bildirilmekte ve Milattan sonra ilk iki yüzyılda Roma'da etkili olan Yunanlı Efes Soranus, annenin bebeği beslenmesine karşı süt anneliğini de desteklemekteydi 
(Dykes, 2002, s. 493). Süt anneliği Antik Yunanistan'da da önemli bir tartı̧̧ma konusu olmuş; örneğin antik filozoflar içinde Platon süt anneliği savunurken, Aristoteles, Cicero ve Plutarch gibi diğer filozoflar; anne-çocuk bağını, bir kadının beklenen görevlerine olan bağlılığını ve çocuğun aile ve devlet sevgisini zayıflattığı için bu fikre karşı çıkmışlardır (Trevino, 2010, s. 491). Her ne kadar bu bakış açısı o dönemde tartışmaya açılsa da, annenin birinci görevinin emzirmek olduğu gerçeği önemini korumaya devam etmiştir.

Sosyal bilimciler tarafından yapılan etnografik çalışmalar, tarih boyunca farklı kültürlerde emzirmenin sadece beslenmeyi ifade etmediği, aynı zamanda karmaşık bir psikososyal, kültürel davranış olduğunu da göstermektedir (Cassidy ve El Tom, 2015, s. 1). Anne sütü beslenme açısından önemli görülürken, emzirmenin çeşitli ilişki biçimlerini belirlemede ve manevi güç sağlamadaki önemi de ayrıca vurgulanmaktadır. Örneğin Romalı erkekler, eşlerinin kölelerinin çocuklarını emzirmeleri durumunda, onların gelecekteki sadakatini sağlayacağına inanması ya da farklı dinlerde yer alan emziren annelerin ikonografisi ve emzirmeye ilişkin yer alan telkinler bunlardan bir kaçıdır. Emziren anneler, Mısır tanrıçası İsis’ten, Yunan Demeter'e (bereket tanrısı), Meryem Ana ve bebek İsa'yı içeren daha sonraki Hıristiyan ikonografisine kadar söz konusu dönemlerin inanç sistemlerinde belirgin bir şekilde yer almış, aynı zamanda Musevi ve İslami metinler de emzirmenin önemini vurgulamıştır (Travino, 2010, s. 491). Anne sütü, bir bebeğin hayatta kalmasını sağlamanın bir yolu olarak görüldüğü için ayrıca önemsenmekteydi. Dykes'in (2002) aktardığına göre Millattan sonra 11. yüzyılda yaşayan Farslı doktor İbni-i Sina (Avicenna), bebeğin optimum sağlığı için emzirmeyi tavsiye etmiş ve sağlıklı annelerin kaliteli süt sağladığına dikkat çekmişti. Konuyla ilgili ilk basılı metin 1473'te Bartholomeus Metlinger tarafından yayınlanmış ve bunu bebek beslenmesi ile ilgili giderek artan bir literatür izlemiştir. Emzirmeye verilen önem aynı zamanda kadının bedeni üzerinden çeşitli söylemlerin geliştirilmesine ve bedenin denetlenmesine kaynaklık ederek, "sağlıkl1," "kaliteli” bir sütün makbul anneliğin önemli bir göstergesi olduğu düşüncesini de desteklemektedir.

Bebek beslenmesi ve emzirme, toplumsal yaşam içinde ahlaki bir mesele olarak da görülmekte ve kadınlık kimliğinin nasıl inşa edildiğini anlamak için bize çeşitli ipuçları sağlamaktadır. Sadece Antik Yunan filozofları değil aynı zamanda aydınlanma dönemi düşünürleri de "makbul” kadının ve "makbul" annenin nasıl olması gerektiğine yer vererek, emzirmeyi, kadının temel görevi olarak değerlendirmekte ve toplumsal cinsiyet rolleri içinde anneliği en üst sıraya yerleştirmektedir (Lee, 2018; Thurer, 1994; Trevino, 2010). Örneğin aydınlanma döneminin filozoflarından Jean-Jacques Rousseau, süt anneliğe karşı çıkarak, emzirmenin biyolojik anne tarafından sürdürülmesi gerektiğini hem ahlâki bir sorumluluk hem de doğal annelik idealini güçlendirecek bir davranış olarak sunmaktadır (Kukla, 2006, s. 159; Lee, 2018, s. 18). Çocuk doğduktan sonra annenin bebeğini emzirmesi, eğer uygun biyolojik koşullar söz konusu değilse süt 
annesi temin etmesi ve çocuk için besleyici bir ortam sağlayarak birincil bakıcı olması gerektiği temel toplumsal beklentiler arasında yer almaktaydı (Crawford, 2010, s. 501). Bu baskın beklentiye karşı kadınlar için görevler hiyerarşisi oluşturulmuş ve kusursuz kadın olmanın temel öncülleri önem sırası ile "eş", "toplumsal görevleri olan kişi”" ve "annelik" olarak belirlenmiştir. Badinter'e (2011, s. 165-166) göre aristokratlar arasında kurulan bu görevler hiyerarşisi içinde emzirme, ilk iki rolü olumsuz etkilediği düşüncesiyle söz konusu dönemin hem kadınları hem de erkekleri tarafından çoğunlukla reddedilmiş ve süt annelik, desteklenen ve kurumsallaşan bir niteliğe bürünmüştür. Buna karşın başta Rousseau olmak üzere bir çok düşünür ve toplumsal ahlâk konusunda kendine misyon edinen otoriteler (düşünürler, din adamları, siyasetçiler), süt anneliğe karşı çıkarak annenin birincil görevinin emzirmek ve çocuğun bakımı olduğunu ifade etmiş̧lerdir (Kukla, 2006; Lee, 2018). Bir yandan kurumsallaşan ve bir mesleğe dönüşen süt annelik ve emzirme tartış1lırken, diğer yandan yaşanan bilimsel ve ekonomik devrimler, bebek beslenmesi konusunda alternatif yöntemlerin gelişmesine kaynaklık etmiştir. Sütlerin çeşitli analiz yöntemleri ile formüle edilmesi, anne sütüne alternatif yapay endüstri ürünü mamaların üretilmesini beraberinde getirerek, bebek beslenmesi konusunda çeşitli dönüşümlerin yaşanmasını sağlamıştır (Fomon, 2001; Lee, 2018; Palmer, 2009; Radbill, 1981; Stevens ve ark. 2009). Formül mamaların, uzmanlar tarafindan desteklenmesi ve önemli bir pazar gücüne sahip olduğunun keşfedilmesi ile birlikte bebek beslenmesi, önemli bir endüstri koluna dönüşmeye başlamıştır (Apple, 1994; Palmer, 2009). Halk sağlı̆̆ı söylemleri içinde, anne sütünün birincil sırada yer almasına rağmen bu gelişmelerin emzirme oranlarını ciddi oranda etkilediği vurgulanmış ve küresel ekonomi içinde bu mamaların artan pazar payına dikkat çekilmiştir (Lee, 2018). Bu gelişmelere paralel olarak bilimsel anneliğin, egemen annelik ideolojisine dönüşmesi ile birlikte bebeklerin beslenmesi, uyku düzeni, emzirilmesi, ek gıda alması ve bütün gündelik rutini; uzman bilgisi aracıllğıyla organize edilmeye başlanmıştır (Thurer, 1994). Öte yandan farklı dönem ve süreçlerde farklı annelik ideolojilerinin toplumda "makbul" anneliğin nasıl olması gerektiğini belirlemesi, emzirme davranışını etkilemektedir. Özellikle 2. Dünya savaşından sonra bilimsel anneliğe karşı doğal annelik mitinin yükselişe geçmesi; emzirmenin halk sağlığı söylemleri içinde önemli konulardan biri olarak görülmesi; emzirme savunuculuğuna ilişkin oluşumların ortaya çıkması (La Leche League (LLL)) ve "meme en iyisi" fikrinin benimsenmesi gibi gelişmeler tekrardan emzirme oranlarının yükselmesini sağlamıştır (Lee, 2018). Büyük küresel mama firmalarının farklı bir pazar stratejisi ile gelişmekte olan ülkelere mama dağıtması ve oradaki anneleri pazarın müşterisi haline dönüştürmeye çalışması, bir çok hastane ve doğum ünitesine ücretsiz süt tozu içeren mamaların verilmesi; hazır mamaların boykot edilmesine ve anne sütünü tekrar teşvik edici girişimlerin başlamasına da neden olmuştur (Porter, 2010). Özellikle İsviçre gida holdingi Nestle, az gelişmiş ülkelerdeki bebekler için süt tozu formülü pazarlaması nedeniyle 1970'lerde tüketici boykotlarına maruz kalmış, satış temsilcileri tarafından ücretsiz numunelerin bu 
ülkedeki doğum birimlerinde dağıtılması ve annelerin toz formüllerin anne sütünden daha iyi olduğuna ikna edilmeleri nedeniyle bu boykot önemli bir etki yaratmıştır (Boyd, 2012, s. 284). Bu ülkelerde yaşayan kadınların daha çok yoksul oldukları ve okur-yazarlık oranlarının düşük olduğu göz önünde bulundurulduğunda; bebek mamasının kullanımı, şişeler, sterilizasyon ekipmanı, yakıt veya buzdolapları için yeterli kaynaklara, güvenli, saf içme suyuna düzenli erişimi olmayanlar; bebek formülü hazırlama talimatlarını okuyamayan ve anlayamayanlar için tehlikeli sonuçlar doğurabileceği tartışılmaktadır (Van Esterik, 2013, s. 514). Boyd'a göre (2012) bir anne hazır sütü kullanıp, bebeğini emzirmeyi bıraktığında, süt üretimi durur ve tedarikçinin kilitli bir müşterisi haline gelir. Dolaysıyla temel amaç pazar ekonomisi içinde hazır sütün talep edilebilirliğini artırarak beslenmenin ekonomi-politiğini oluşturmaktır. Günümüzde ise tıbbi ve kültürel söylemler iç içe geçerek egemen annelik ideolojisini, emzirmeye ilişkin politik ve toplumsal bakış açısını şekillendirmekte, bebek beslenmesi konusunu hem bireysel hem politik bağlam içine yerleştirmektedir.

\section{Bir Beslenme Süreci Olarak Emzirme ve Sütün Metalaşmasına Yönelik Tartışmalar}

Bebek ve çocuk beslenmesi sadece fizyolojik bir olay olarak değil, aynı zamanda ekonomik, kültürel ve dini bir mesele olarak da ele alınmaktadır. Modern-devletlerin ortaya çıkması ile birlikte beslenme ve özellikle çocuk beslenmesi ekonomik-politik bir mesele haline gelmiştir (Şişman, 2014, s. 41). Emzirmeyi teşvik edici politikaların yanı sıra bilimsel gelişmelerin 1şığında sütün formüle edilerek şişelenmesi yeni ve büyük bir endüstri alanının gelişimine kaynaklık ederek, sütün kapitalist sisteme entegre edilmesini ve ticari bir metaya dönüşmesine de neden olmuştur. Palmer'in (2009) "Emzirme Politiktir" adlı çalışması bebek beslenmesinin kapitalistleşen boyutunu tartışırken, emzirmenin nasıl politik bir mesele olduğunu da ele almaktadır. 18. ve 19. yüzyılda yaşanan bilimsel ve endüstriyel devrimlerin ardından Batılı bilim insanları bebek beslenmesine yönelik alternatif yöntemleri incelemeye başlamış; hayvan sütlerinin analiz edilmesi ve sütün formülize edilerek şişelenmesi bu çabaların bir ürünü olarak ortaya çıkmıştır. Bir yandan bilimsel iyileştirici tıbbın toplumda odak noktası haline gelmesi, öte yanda ticari kaygıların ön planda olmasının bebek beslenmesi alanını da etkilediğini tartışan Palmer'e göre (2009) süt ve mama endüstrisi önemli bir kazanç alanına dönüşmüştür. 1865 yılında kimyager Justus von Liebig'ın, önce sıvı halde ve daha sonra raf ömrü uzun toz bebek maması geliştirmesi ve bunları patentleyerek pazarlamaya başlaması, bebek beslenmesinin ticarileşmesinin önemli bir adımı olarak değerlendirilmektedir. Nitekim İnek sütü, buğday, malt unu ve potasyum bikarbonattan oluşan Liebig formülü "mükemmel" bir bebek maması olarak kabul edilmiştir (Radbill, 1981, s. 619).

Gıdaların saklanması ve sterilize edilmesi için geliştirilen yöntemler ile birlikte farklı araç ve teknikler kullanılarak raf ömrü uzun yeni sütler üretilmiş ve bu üretilen 
sütlere şeker eklenerek 1853 yılında "Eagle" adıyla satışa sunulmuştur (Radbill, 1981, s. 619). 1883 yılına gelindiğinde ise 27 marka patentli bebek maması üretilmeye başlanmış (Fomon, 2001, s. 409) ve artan talep, gelişen teknoloji ve bu ürünlerin önemli bir kâr aracına dönüşmesi ile birlikte farklı yöntem ve içeriklerle üretilmiş formül mamaların, bebek beslenmesinde önemli yer tutarak emzirme oranlarını etkilediği tartış1lmıştır (Fomon, 2001; Palmer, 2009; Radbill, 1981; Stevens ve ark., 2009). Bu durum üzerinde 20. Yüzyılın başlarında anne sütünün miktar ve kalite açısından bebeğin beslenmesi için yetersiz olduğu söylemleriyle yeniden tanımlanması ve doktorların, daha modern ve bilimsel bir seçenek olarak formül mamaları önermeleri etkili olmuştur (Apple, 1994). Günümüzde de önemli bir küresel pazara sahip olan formül mamalar yaygın şekilde tercih edilen bir seçenek olmaya devam etmekte olup 2009 yılında küresel düzeyde bebek gıdalarının satışının üçte ikisinin bebek maması satışlarından geldiği (20,2 milyar ABD doları) ve 2007 yılında ABD'nin bebek maması pazarının 3,9 milyar dolar olduğu tahmin edilmektedir. Üçüncü dünya çapında ihracat yapan sadece bir İngiliz şişe ve emzik şirketinin yıllık 90 milyon sterlin ciroya sahip olduğu tartışılmaktadır (Palmer, 2009, s. 20). Güncel veriler, küresel bebek gıdalarının ve bebek maması pazarının 2018'de 52,9 Milyar ABD Doları değerine ulaştı̆̆ını göstermekte ve pazarın 2024 yılında 74,4 Milyar ABD Doları değerine ulaşması beklenmektedir (https://www.researchandmarkets.com/reports/4763157/baby-foodand-infant-formula-market-global). Bu konuda dikkat çekici noktalardan biri de bebek maması üreten firmaların hem gıda hem de ilaç tabanlı büyük firmalar oluşu ve özellikle II. Dünya Savaşı'ndan sonra Batı toplumlarında azalan doğum oranlarına paralel olarak gelişmekte olan ülkelerde pazar yaratma çabasıdır (Van Esterik, 2013, s. 512).

Çocuk beslenmesinin endüstriyel bir alana dönüşmesi ve büyümesi devam ederken, anne sütüne ilişkin politik, kültürel ve tıbbi söylemin düzenleyici etkisi de artmış, bu söylemlerin odağında süt bankalarının kurulması ve anne sütünün depolanması konusu gündeme gelmiştir. Amerika Birleşik Devletleri'nde, yirminci yüzyılın başlarında pediatrinin yükselişine paralel olarak çocuk beslenmesi önemli bir mesleğe dönüşerek özellikle bebeklerin sağlıklı bir şekilde emzirilmesi ve yeni doğan ölümlerinin azaltılması önemli bir toplumsal meseleye dönüşmüştür. Bir yandan inek sütünün iyileştirilmesine yönelik çabalar, öte yandan süt anneliği tartışmaları sürerken, doktorlar hem tıbbi kullanım hem de araştırma amaçlı olarak anne sütünü toplamaya başlamış ve böylelikle ilk süt bankalarının kurulmasında bu çalışmalar önemli rol oynamıştır. İlk süt bankaları 1909 yılında Viyana'da (Demirtaş, 2010, s. 74) ve 1910 yılında Boston'da bir çocuk hastanesinde kurularak anne sütünün bedenden bağımsızlaşmasını ve kurumsal bir zeminde beslenmeyi sağlayan bir araç olarak görülmesini sağlamıştır (Palmquist, 2015, s. 26-27). 1970'lerde emzirme savunuculuğu hareketi ile birlikte tekrar gündeme gelen süt bankalarının sayısı artmış ve dünyanın farklı yerlerinde kurulması söz konusu olmuştur. 
Dünya Sağlık Örgütü (WHO), bir bebeğin emzirilemediği durumlarda en iyi seçeneğin annenin sütünü sağarak veya sağlıklı bir süt anneden ya da bir insan süt bankasından alarak beslemek olduğunu kabul etmiştir (Cassidy; El Tom, 2015, s. 2). Süt bankaları aynı zamanda erken doğan bebeklerin yaşamsal fonksiyonları için hastanelere anne sütünün tedarikini sağlamaktaydı (Palmquist ve ark., 2019). Böylelikle emzirme ve anne sütüne ilişkin bakış açısı da dönüşüme uğramış ve emzirmenin bağ kuramı ile anne-çocuk arasındaki ilişkinin önemli bir aşaması olarak kabul edilebilirliğini de tartışmalı kılmıştır. 1980'lerde HIV/AIDS'in ortaya çıkması, anne sütü yoluyla hastalık bulaşmasına ilişkin endişeleri artırmış ve süt banklarının bu süreçte kapanması ve talep edilebilirliğinin azalması söz konusu olmuştur. Öte yandan bu gelişmelerin sonucu tıbbi gözetimin süt toplama ve dağıtımı üzerindeki kontrolün gerekçelerinin oluşturulduğu ve kadın bedenine yönelik müdahalenin yolunun açıldığ da ele alınmıştır (Palmquist, 2015, s. 27). Süt bankaları günümüzde halk sağlığı tartışmalarına dahil edilerek bir çok ülkede hükümetler tarafından kurulmakta olup bunun yanı sıra, gönüllü sivil toplum kuruluşlarının ve özellikle emzirme savunucusu aktivist kadın gruplarının çabaları sonucu bağışlanan sütlerin toplanması ve ihtiyaç sahiplerine ulaştırılması üzerinden de faaliyet göstermektedir. özellikle bebek beslenmesinin kapitalistleşen ve ticarileşen boyutuna bir tepki olarak ortaya çıkan bu faaliyetler, hazır mamaların sağlık üzerindeki etkilerine de dikkat çekmektedir.

Süt bankasının kurulması büyüyen hazır mama endüstrisine karşı ve halk sağlığı çalışmalarında önemli bir gelişme olarak okunurken, bir biri ile çatışan söylemlerin konuya ilişkin yürüttükleri güç savaşlarını da görünür kılmaktadır. Çünkü anne sütünün anneden bağımsız bir şekilde ele alınması üzerinden de değerlendirilen bu bankaların kurulmasının, yeni toplumsal ilişki biçimlerini oluşturacağı, annelik ve bebek bakımına ilişkin yeni tanımlamalar geliştireceği ve sütün metalaşma durumunu pekiştireceği düşüncesinden hareketle farklı söylemler ve tartışmalar geliştirilmiştir. Özellikle emzirmenin annenin bedeninden soyutlanarak farklı ortamlarda ve materyaller ile gerçekleştirilmesi durumu konunun ahlâki, ekonomik, tıbbi, dini ve hukuksal bir niteliğe bürünmesini sağlamakta, Türkiye gibi geleneksel ilişki formlarının hakim olduğu ülkelerde süt bankalarının kurulmasına ilişkin ahlaki ve dini söylem baskın bir forma bürünmektedir (Şişman, 2014, s. 42). Türkiye'de süt bankalarına ilişkin tartışma 2013 yılında Sağlık Bakanlığı tarafından bir proje olarak gündeme getirilmiş, kültürel 
ve dini söylemin etkisi ile faaliyet göstermesi uygun görülmemiştir'. Bu durum, emzirme ve anne sütüne ilişkin tutumun ve uygulamaların sadece bireysel bir davranış veya bir beslenme meselesi olmadığını aynı zamanda toplumsal-kültürel ve dini bir mesele olduğunu göstermektedir. Bir yandan emzirme doğal bir süreç olarak kabul edilirken, öte yandan yönetilebilecek, yönlendirilebilecek ve metalaştırılabilecek bir eylem olarak da ele alınmaktadır.

\section{Tibbi Bir Mesele Olarak Emzirme ve Bebek Beslenmesi}

Dünya Sağlık Örgütünün (2016) emzirmenin hem bireysel hem de toplumsal ve ekonomik faydalarına odaklanarak, halk sağlığının önemli bir aşaması olarak görmesi, konunun tıbbi bir meseleye dönüşmesini de beraberinde getirmektedir. Emzirme, çocukların hastalık ve ölüm oranlarını azaltması (ishal ve solunum yolu enfeksiyonu ataklarını azaltması), sağlık bakım maliyetlerini düşürmesi, emziren annenin yumurtalık ve meme kanseri riskini azaltması gibi bazı katkıları bakımından faydalı bir süreç olarak görülmektedir. Bebek beslenmesinde en sağl1kl gıda olarak kabul edilen anne sütü, ister yüksek gelirli ister düşük gelirli ülkelerde olsun çocuklar ve kadınlar için önemini gösteren araştırmalarla desteklenmektedir (WHO, 2016). Tibbi söylemin emzirme ve çocuk beslenmesi üzerinde söz sahibi olması ve önemli bir iktidar alanına dönüşmesinin arka planında; pediatrinin gelişmesi, 19. yüzyılda ve 20. yüzyılda sütün bilimsel analizleri için yapılan çalışmalar, bilimsel anneliğin sınırlarının çizilmesi gibi etkenler yatmaktadır (Palmer, 2009). Özellikle anne sütünün çeşitli araştırmalarca faydalarının kanıtlanması ve hastalık-sağlık durumu üzerindeki doğrudan etkisinin ortaya konulması meseleyi hem

1 Türkiye'de süt bankalarının açılmasına yönelik talep 2013 yılında Sağlık Bakanı Mehmet Müezzinoğlu döneminde gündeme gelmiş, hukuki ve bilimsel alt yapısı yeterli olmadığı gerekçesi ile proje ertelenmiştir. projenin gündeme geldiği dönemde, dini söylem konuya ilişkin yürütülen tartışmalara dahil olmuş, süt bankasına süt verecek annelerin kim olduğu bilinemeyeceği için ilerde bu annelerin çocukları arasında yapılacak evliliklerin dinen uygun olmayacağ tartışılmıştır (https:// www.haber7.com/guncel/haber/1006885-bakanlik-anne-sutu-bankasi-projesini-rafa-kaldirdi). Diyanet İşıreri Başkanlı̆̆ı'ndan da konuya ilişkin yazılı bir açıklama yapılmış, "Ancak bu hüküm meselenin özüne yönelik olmayıp, kendilerinden süt alınan anneler ile süt verilen bebekler arasinda oluşacak süt akrabalığı konusunda hassasiyet gösterilmeyerek, sütlerin ve süt akrabalıklarının karışması sonucu dinin yasakladiğı evliliklere götürebileceği endişesinden kaynaklanmaktadır." İfadeleri ile süt bankaların ahlaki ve dini açıdan uygun olmadığı belirtilmiş (https://www.hurriyet. com.tr/gundem/diyanetten-anne-sutu-bankasi-aciklamasi-22691568), ancak şu hususlara dikkat edileceği sürece aç1labileceği de vurgulanmıştır: "Süt verecek kadının kendi çocuğunu sütten mahrum bırakmaması; başka kadının sütünü içen çocuklar arasında oluşacak mahremlik dairesini, olabildiğince daraltmak için, pratik bir tedbir olarak, bir kadından alınan sütün sadece erkek veya sadece kız çocuklara verilmesi; Süt veren kadın ile süt verilen çocuğun kimliklerinin, kayıt altına alınması ve bu bilginin her iki tarafa da verilmesi; bu hususun yasal düzenleme ile güvence altına alınmast, evliliğe engel teşkil eden süt akrabalı̆̆ dairesinin daha da genişlememesi için, birden fazla anneye ait sütlerin karıştırlmamasl, süt veren anneye, masrafları dişında bir ücret verilmemesi, alınan sütlerin para karşılığı satılmaması, kendi annesinin sütü ile beslenme imkanı bulunan çocukların, bu sistemden yararlandırılmaması. "(http://www.gidahareketi.org/Diyanet-ten-AnneSutu-Bankasi-Konusunda-2-Ayri-Yaklasim-1669-haberi.aspx). 
tıbbileşitirmiş, hem de politikleşmesine neden olmuştur. Nitekim Vancour'un (2010, s. 142-153) farklı çalışmalardan derleyerek ortaya koyduğu bulgular, anne sütünün neden bir halk sağlığı sorunu ve tıbbi bir mesele olduğunu tartışmaktadır. Bu araştırmalar; anne sütünün bebeklerin sindirimini kolaylaştırdığını, büyüme ve gelişim için gerekli olan yağı, şekeri, suyu ve proteini içerdiğini ortaya koymaktadır. Yine yapılan çalışmalar, emzirilen çocukların formül beslenen çocuklardan biraz daha yüksek IQ'ya sahip olduklarını ve ani bebek ölüm sendromu, tip1 ve tip2 diyabet, astım, yüksek kolesterol, aşırı kilo ve obezite oranlarının düşük olduğunu göstermiştir. Yeni anne olanlar için, emzirme bazı meme ve yumurtalık kanseri riskini azaltmaya, gebelik kilolarının kaybını artırmaya, uterusu küçültmeye (böylece kanamayı azaltmaya), yumurtlamanın ve menstrüel siklusların geri dönüşünü geciktirmeye, kalça kırıkları ve osteoporoz riskini azaltmaya yardımcı olabileceği de tartışılmaktadır (Voncour, 2010). Anneliğe ilişkin egemen kültürel ve toplumsal söyleme paralel olarak tıbbi söylem de bebek beslenmesi ve emzirme konusunda üretilen bilgi birikime müdahil olarak bir güç alanına dönüşmekte ve bebek beslenmesinin tıbbileşmesini sağlamaktadır. Tıbbın doğal yaşam süreçleri üzerinde artan kontrolüne göndermede bulunan tıbbileştirme kavramı; tıbbi güç ve bu gücün beraberinde getirdiği iktidar ilişkileri ile açıklanmaktadır. Tıbbi olmayan konuların tıbbın alanına dâhil edilerek tanımlanması ve tıbbın sosyal kontrol yönüne vurgu yapan tıbbileştirme, özellikle kadın bedenine ilişkin süreçler üzerinden işlemektedir (Conrad, 1992; Zola, 1972). Hamilelik, doğum ve emzirme tıbbi pratiklerin uygulama alanı bulduğu ve üzerine söz sahibi olduğu ve en çok söylem ürettiği alanlardan bazılarıdır. Anne sütünün tıbbileşmesi ise, anne sütünün bilimsel test, gözetim ve düzenleme gerektiren tıbbi bir madde olarak tanımlanma şeklini ifade eder (Palmquist, 2015, s. 26).

Tıbbi bilginin her geçen gün gündelik hayatı organize eden bir faaliyet ve iktidar alanına dönüşmesi ile birlikte konuya ilişkin farklı bakış açıları ve tartışmalar yürütülmüştür. Nitekim konuya ilişkin Fransız düşünür Foucault'nun çalışmaları söz konusu toplumsal yaşama içkin olan güç ve iktidar ilişkilerini çözümlemede önemli açılımlar sunmaktadır. Foucault'ya göre (2002) tıp mesleği tarihsel olarak ayrıcalıklı ve saygın bilimsel bilginin kontrolü yoluyla gerçekliği tanımlamak için hatırı sayılır bir güç kazanmıştır. Tıbbi bilgi, normallik ve sapmanın sınırlarını belirlemekte ve aynı zamanda bedenlerimizi de tıbbi sistemin gözetimi ve kontrolü altına alınması gereken nesneler haline getirilmesini sağlamaktadır. Böylece ideoloji düzeyinde tıp, hangi bedenlerin, faaliyetlerin ve davranışların normal olduğunu tanımlayan söylemler yaratarak, kurumsal düzenlemenin ve disiplininin temel kaynağı haline gelmektedir (Pylypa, 1998, s. 30). Nasıl ve ne kadar süre ile emzirileceği, farklı kültürel ve toplumsal dinamikler göz ardı edilerek emzir(e)meyen annelerin veya emzirilmeyen çocukların anormal olarak kabul edilmesi, hem beslenmenin hem de emzirmenin tıbbileşmesine işaret eder. Nitekim Pylypa'nın da (1998, s. 33) tartıştı̆̆ gibi emzirme davranışı ve anne sütü üretimi arasındaki ilişkinin bilimsel olarak tam anlaşılmamasına ve önerilen programlar bebeklerde açlık yaratma eğiliminde olmasına rağmen planlı emzirme tıp 
topluluğu tarafından bebekler ve anne için biyolojik olarak doğuştan gelen bir norm olarak kabul görmektedir. Düzenli bir programın olmaması, anne veya çocuğun anormalliğinin bir işareti olarak kabul edilmekte; planlı ve disiplinli olma davranış1 ile gündelik yaşam faaliyetleri organize edilerek, mikro iktidarın gözetleyici denetimine tabi olmaktadır. Böylelikle tıbbi bilginin günlük yaşamın mikro düzeyenlerine kadar etki etmesine ve kendine iktidar alanı yaratmasına, yeni bir uzmanlık alanının kadın bedeni üzerinde kendine uygulama zemini yaratmasına da neden olmaktadır. Son yıllarda emzirme danışmanlığı diye ayrı bir mesleğin ortaya çıkması ve git gide talep edilen popüler bir mesleğe dönüşmesi aynı zamanda önemli bir ticari alan yaratmaktadır.

Riessman'ın (1983, s. 4) ele aldığı gibi tıbbileştirme yoluyla, "doğal” davranışlar veya koşullar tıbbi anlamlar alır ve bu davranışlar "sağlık" ve "hastalık" açısından tanımlanır. Tıbbileştirme her geçen gün kapsamı genişleyen bir tanıma dönüşerek, bireylerin uzmanlara olan bağımlığına ve onlara danışılmasını gerektiren alanların varlığını da işaret etmektedir. Beslenme konusunda günümüzde uzmanlara olan bağımlılığın artması, sadece neyin tüketilmesi gerektiği değil; ne kadar, nerde ve nasıl tüketeceğinin de belirlenmesini içermektedir. Beslenme rejimlerinin düzenlenmesi, diyet listelerinin oluşumu, günlük kalori hesabının yapılması, gıdaların kalitesi, "sağlıklı" ve "sağlıksız" besinler, doğal/ekolojik yaşam bu kapsamda tıbbi otoritelerin ilgi alanını oluşturmaktadır. Benzer şekilde bebeğin beslenmesi ve "kaliteli", "yeterli" süt üretebilmesi adına annenin beslenmesi de uzanmaların ilgi alanını oluşturarak, iktidarın mikro ölçekte gündelik hayatta olan müdahalesine işaret etmektedir. Bebek beslenmesinin ve emzirmenin tıbbileştirilmesi aynı zamanda tıbbın kapitalist üretim ilişkileri içinde önemli bir kâr alanına dönüşmesi ve çok sayıda ilaç, ek gıda, süt artırıcı takviyeler, vitamin gibi ürünlerin piyasada tüketiciye sunulmasıyla da ilgili olmaktadır. Böylelikle tıp sadece iktidar ilişkileri içindeki konumu ile değil aynı zamanda üretim ilişkileri içinde önemli bir sanayi dalına dönüşmesi bakımından da tartışmaya açılmaktadır (Ersoy, 2001). Annelik ve bebek beslenmesi konusunda çok sayıda ürünün tüketicinin onayına sunulması ve konuya ilişkin her aşamanın aynı zamanda kapitalist sisteme entegre edilerek bir kâr alanı olarak kurulması, tıp ve kapitalizmin iş birliğini de gerekli kılmaktadır. Örneğin bir ürün olarak göğüs pompaları bir yandan emziremeyen kadınlar için önemli bir araç olarak görülürken öte yandan Van Esterik'in (1996, s. 273) belirttiği gibi, emzirmenin tıbbileşmesine katkıda bulunur ve anne sütünü emzirme süreci olarak tanımlamak yerine bir ürün olarak algılar ve vurgular.

Sadece emzirmeye ve anne sütüne ilişkin süreçler tıbbın denetimi altına girmemekte, aynı zamanda bebek beslenmesi endüstrisinin önemli ürün grubunu oluşturan bebek mamalarının kullanımı, dağıtım ve pazarlanması konusu da tıbbın ilgi alanına oluşturmaktadır. Nitekim doğum hastaneleri ve çocuk sağlığ klinikleri geliştikçe mamaların kullanımının artması bu durumun bir göstergesi olarak tartışılmaktadır (Dykes, 2002, s. 494). Tıp camiasında doğal beslenmenin tıbbileşmesi, formül 
üreticilerinin sağlık ortamlarında etkisi ve kitlesel varlığı ile daha da kanıtlanır ve güçlendirilir. İlaç şirketleri tarafından hastanelere ve tıbbi ofislere dağıtılmak üzere sağlanan yapay beslenme ürünlerinin kurumsallaştırılmış dağıtımı, genel tıbbi bakımın doğal beslenmeye karşı çalıştı̆̆ bir başka yol olarak da tartışılmaktadır (Wallace ve Chason, s. 2007, s. 410). Öte yandan formül mamalara karşı geliştirilen kampanyalar ve girişimler, iki farklı çatışmalı söylemin varlığına işaret ederek, emzirmeyi tekrar tıbbi söyleme dahil etmektedir. Buna ilişkin çarpıcı örneklerden biri, yeni sağlık paradigmasının hastalık ve sağlı algısı üzerinden riskin pazarlanmasını ve yönetimselliğini sağlaması ve konuya ilişkin süreçleri ahlaki bir meseleye dönüştürmesidir (Lee, 2007; Murphy, 2000). Sağlık bir yandan bireyselleştirilmekte, öte yandan toplumsal ve politik bir mesele olarak yeniden inşa edilmektedir. Dolayısıyla emzir(e)memek riskli bir davranış olarak tıbbi söyleme dahil edilmekte ve formül mamaların kullanımı bu riskin hesaplanması üzerinden tercih edilebilirliği tartışmaya açılmaktadır. Yeni sağlık paradigmasını açıklayan kavramlardan biri de sorumluluk ve bunun yarattığı kültürdür. Wolf'a göre (2010, s. xvi). neoliberal anlayış içinde bilim insanları, doktorlar ve devlet kurumları bireysel sorumluluğu vurgulamakta ve "iyi" vatandaş kendine bakan ve kişisel kontrol uygulayan bireyler olarak idealize edilmektedir. Böylelikle neoliberal risk kültürü, kişisel sorumluluk kültürü olarak da tanımlanarak; çocukların sağlığına yönelik risklerin azaltılması annenin sorumluğuna bırakılarak, kamusal söylemler şekillenmektedir. "İyi” ve "ideal” annenin ölçütlerinin bu risklerin minimalize edilmesi üzerinden ölçülmesi söz konusu olmakta, dolayısıyla farklı anneliklerin (kadının çalışma koşulları, sınıfsal, ırksal, cinsel yönelim farklılıkları göz ardı edilerek) dışlandığı kültürel ve ahlaki normlar da söz konusu olabilmektedir.

Emzirme bir yandan hem tıbbi hem de kültürel bir gereklilik olarak kabul edilirken, öte yandan bu söylemlerin ürettiği hegemonik güç ile birlikte anne sütünün ticarileşmesi ve dolayısıyla metalaşmasını söz konusu olmaktadır. Süt bankaları, anne sütü satışı, bu metalaşma sürecinin bir örneği olarak değerlendirilmekte ve çoğu yerde tıbbi söylemin, dini söyleme entegre edilerek konuya ilişkin söz sahibi olduğu görülmektedir. Öte yandan tıbbi söylemin emzirmeyi desteklemesi ve halk sağlı̆̆ına entegre edecek politikaların oluşmasına aracılık etmesi konuyu farklı bir boyuta taşıyarak, biyopolitk gücün annelik ve kadın bedeni üzerinden nasıl bir müdahale alanı yarattığını da tartışmayı gerekli kılmaktadır.

\section{Biyopolitik Bir Mesele Olarak Bebek Beslenmesi ve Emzirme}

Dünya Sağlık Örgütü'nün tüm kadınların en az altı ay boyunca bebeklerini sadece emzirmelerini ve en az iki yaşına kadar emzirmeye devam etmelerini önermesi, çoğu ülkelerin konuyu, politik ve tıbbi söylemlerine dahil etmesini sağlayarak, aynı zamanda emzirmenin bir halk sağlığı meselesine dönüşmesine ve dolayısıyla biyo-politikleşmesine yol açmıştır. Sağlıklı nüfusların teminatı için önerilen anne sütü, çeşitli politikaların ve makro iktidarın da merkezi söyleminde yer almaktadır. Kadın bedeninin 
tıbbileştirilmesine karşı direnişe rağmen, tıbbi ve halk sağlı̆̆ söylemleri sıklıkla "meme en iyisi" fikrini desteklemiştir. Bu kez tıbbi ve politik söylemler, annelerin çocuklarının hayatlarına en iyi şekilde başlamalarını sağlamak için verebilecekleri en iyi yiyecek olarak anne sütünün bilimsel olarak meşrulaştırılması üzerinde yoğunlaşmaktadır. Anne sütünün avantajları çok sayıda bilimsel araştırmalarla desteklenmekte ve bu araştırmalar, emzirme ile ilgili kamu sağlığı müdahalelerini ve politikalarını büyük ölçüde şekillendiren bir anlatıya da dönüşmektedir (lburo-Caeñte, 2014, s. 118). Çünkü günümüzde sadece çocuk beslenmesi ve emzirme değil, başlı başına beslenme artan obezite ve kronik hastalıklar yüzünden bir halk sağlığı sorununa dönüşmekte, politik ve tıbbı söylemin merkezinde yer almaktadır. Bu bağlamda tüm yiyecek ve içeceklerin vitamin, kalori değerleri hesaplanarak hastalık ve insanların sağlık durumları üzerinde etkisi tıbbi otoriteler tarafından tartışılmaktadır. Nitekim sağlıklı nesillerin yetişmesi için emzirme ve çocuk beslenmesi de önemli bir mesele olarak görülmekte ve biyopolitik söyleme tabi kılınmaktadır. Foucault'nun üzerinde durduğu biyoiktidar, bilgi ve ç̧eşitli güç stratejileri yoluyla nüfusun yönetimselliğini içermekte ve doğum-ölüm, sağlık, hastalıkla gibi konularla ilgilenmektedir (Foucault, 1993, 2001; Revel, 2005).

Foucault, biyo-politk gücü, insan türü ve insan bedeni olmak üzere iki kutupta faaliyet gösteren olarak görselleştirir. İlki "nüfusun biyo-politikası" ile ilgili olup, çoğalma, ölüm ve morbidite gibi konulara bilimin uygulanması yoluyla nüfusların düzenlenmesini içerir. İkincisi, bireysel bedenlerin manipülasyonu ve kontrolü ile ilgili olup disiplin teknikleri üzerinden işleyerek bir tür yönetimsellik geliştirir. Disiplin teknikleri zaman, mekan ve günlük uygulamaları organize eder; bu teknikler okullarda, hapishanelerde, hastanelerde ve atölyelerde kurumsallaştırılır, aynı zamanda bireylerde kendi kendini düzenleyen davranışlarla içselleştirilir (Pylypa, 1998, s. 23). Böylelikle hükümetler doğum ve ölüm oranları, hastalık oranları, doğurganlık, cinsel aktivite oranları, yaşam beklentisi, göç ve beslenme gibi değişkenler üzerinde artan kontrol uygulamaktadır (Lee, 2018, s. 36). Alianmoghaddam ve arkadaşları (2017, s. 7) Dünya Sağlık Örgütün' nün raporlarından yola çıkarak kadın bedeninin çeşitli maliyet hesaplarına nasıl konu olduğunu, hükümetlerin emzirmeyi teşvik ederek her yıl 300 milyar ABD dolarından daha fazla tasarruf sağlayabileceği üzerinden tartışmaktadır. Bu bağlamda emzirme Foucault’nun bilgi ve güç stratejileri yoluyla bir nüfusun yaşam güçlerinin yönetimi olarak adlandırdığı biyoiktidara tabidir (Lee, 2018, s. 37). Biyoiktidar aynı zamanda insan vücudunu manipüle edilecek ve eğitilecek bir nesne olarak hedefleyen disiplin gücü içererek, kadınlara emzirme tekniklerinin nasıl gerçekleştirileceği konusunda kesin ve spesifik tavsiyeler veren bir anatomi politikasıdır. Bebek beslenmesinin sadece annenin görevi olmadı̆̆ aynı zamanda hükümetlerin, sağlık kuruluşlarının, endüstrinin ve daha geniş toplumun işi haline geldiği de bu bağlamda tartışılan bir meseledir (Marshall ve ark., 2007). Bu noktada Rothman'ın (2000) üç farklı ideolojiye göndermede bulunarak anneliğin sosyal olarak nasıl inşa edildiğine ve kadın bedeninin bir dizi müdahaleye nasıl konu olduğuna yönelik yaptığı çözümleme emzirme konusuna da önemli aç1lımlar getirmektedir. Patriarkal, teknolojik 
ve kapitalist ideoloji olarak tanımladığı bu üç yapı birbiri ile iş birliği içinde kadınların bedenlerine ve gündelik hayatlarına müdahale ederek, toplumsal ilişkiler içinde konumunu belirlemekte ve onları güç ilişkilerine tabi kılmaktadır. Patriarka kadınların bedeni, cinselliği, yeniden üretim sürecindeki rolü ve emeği üzerinde erkek egemenliğine işaret ederken, teknoloji ise kadınların bedenleri üzerinde tıbbi müdahaleler aracıllğ̆ ile doğrudan denetim kurmasına işaret etmektedir. Beden ve teknoloji ilişkisinde tıp kurumu ön plana çıkmakta, beden bir makine olarak görülmekte ve tıbbi müdahaleye açı hale getirilmektedir. Özellikle annelik üzerinden kadın bedenine müdahalenin yolu açılmakta ve doğurganlık durumu, hamilelik, doğum, emzirme gibi konular tıbbileştirilerek biyopolitik söyleme tabi k1lınmaktadır. Rothman'a göre (2000) kapitalizm ise ataerkil ideoloji ve teknolojinin yardımıyla kendi sisteminin devamını sağlayacak, üretim ve tüketim ilişkileri içinde kârını maksimize edecek şekilde toplumsal cinsiyet ilişkilerini yeniden üretmektedir. Bu üç ideoloji birbiri ile iş birliği içinde toplumdaki hiyerarşik güç yapılarını oluşturmakta, sosyal olayların anlamını belirleyebilmektedir. Dolaysıyla bu üç ideoloji; emzirmenin ve kadın bedeninin, neden biyopolitikanın, tıbbi gücün, gündelik hayatı düzenleyen diğer makro ve mikro iktidar yapılarının (diğer toplumsal kurumlar, hükümetler, mikro ölçekte faaliyet gösteren kuruluşlar, gruplar, ticari şirketler), merkezinde yer aldığını anlamamıza olanak tanır. Çünkü biyoiktidar aynı zamanda Rothman'ın bahsettiği bu üç ideoloji yardımıyla toplumsal cinsiyet rejimlerine etki eden güç ilişkilerini yeniden düzenlemekte ve bebek beslenmesini kadınların biricik görevi olarak tanımlayarak, bedenlerini ve gündelik faaliyetlerini organize etmektedir.

Emzirmenin iyi, verimli bir şekilde gerçekleşmesi için anne sağlı̆̆ ve bedeni de biyopolitik söylem için önemli bir mecraya dönüşerek, kadının gündelik yaşamdaki en basit faaliyeti bile baskı aracına dönüşebilmektedir. 1960'ların sonlarında başlayan doğal annelik hareketi² ve 1970 'lerin sonlarında gelişmekte olan ülkelerde bebek maması

2 Doğal annelik hareketi, II. Dünya savaşından sonra bebek beslenmesinde büyüyen formül mama pazarına ve azalan emzirme oranlarına karşı bir tepki olarak ortaya çıkarak, emziremeyen annelere gönüllü destek veren kuruluşların yürüttügü bir hareketi ve ideolojiyi temsil etmektedir. Bu hareketin önemli temsilcilerinden biri de anneden anneye" yardım sağlamak amacıyla ABD'de beş kadın tarafından kurulan ve daha sonra tüm dünyada örgütlenen gönüllü bir kuruluş olan La Leche League'dir (LLL). Doğal annelik hareketi "iyi”" annelik ideolojisi temelinde önceliklerini belirmekte ve çocuğun ihtiyaçlarını merkeze koyan, onu gidermeye çalışan bir tutumu benimsemektedir. Bu bağlamda, emzirme, bebeği anlamanın ve ihtiyaçlarını tatmin etmenin en doğal ve etkili yolu kabul edilmekte, çocuk ve annenin iyi bir ilişki kurması için çok erkenden ve sık sık temas etmeleri gerektiğine inanılmaktadır. Doğal annelik, anne memesinden emilen sütü, çocuk için en mükemmel besin kabul eder ve emzirmenin bebek arzuladığı sürece devam etmesi ideal olarak kabul edilmektedir. Doğal doğum, emzirmenin başlamasına etkili olduğu için desteklenmekte ve çocuğun iyi beslenmesi annenin doğal ürünlerin tüketilmesine bağlı olduğu savunulmaktadır (Bkz: Banditer, 2011). Doğal annelik ideolojisi "iyi", "ideal", "yoğun", "mükemmel" "momism" (annecilik) annelik ideolojisi ile bütünleşik bir şekilde anneliğin formalarını da belirlemiştir. Çocuğun istek ve arzularını merkeze koyan, kendi istek ve arzularını bastıran, çocuk her istediğinde yanında olan, ona sevgi ve şefkat gösteren, emziren, tüm zamanını ona harcayan bir annelik formuna işaret eden bu ideolojilerin, anneler üzerinde yarattığ (Bkz: Douglas ve Michaels 2004; Hays 1996, Henderson ve ark. 2010; Uzogara, 2015). 
pazarlamasına karşı çıkan Nestlé boykotu, bebek mamasına ilişkin riskleri ve emzirmenin yararları hakkında farkındalığı arttırma çabaları, emzirmeyi halk sağlı̆̆ kampanyalarının önemli bir parçası haline getirmiş̧tir. Böylelikle, 1970’lerin sonlarına doğru, emzirmenin sağlık yararları konusunda bilimsel farkındalık önemli ölçüde artmış ve 1980'lerin başında emzirmeyi teşvik etmek için halk sağlığı kampanyalarının yenilenmesine yol açmıştır. Lee’ye göre (2018, s. 6) günümüzde anne sütünün sağlık, psikolojik ve gelişimsel avantajlarını gösteren büyük araştırmalar sonucunda emzirme, bebek sağlığını geliştirmeye yönelik kapsamlı halk sağlığı kampanyalarının konusu olmuştur.

Alianmoghaddam ve arkadaşlarının (2017) yaptı̆̆ çalışmaya göre uluslararası kuruluşlar ve ulusal hükümetler, kötü alışkanlıklardan dolayı ortaya çıkan hastalıkların maliyetini azaltmak için insanları daha sağlıklı yaşam tarzları seçmeye teşvik eden politikalar izleyerek nüfusun yönetimselliğini sağlamaktadır. Emzirmeye yönelik programların geliştirilmesi de biyo-politikanın nüfus üzerinde hem biyolojik, hem ekonomik hem de siyasi bir denetim kurması amacını içererek, beden politikalarının etkili örneğini oluşturmaktadır. Sağlık profesyonellerinin hükümetlerin kontrolünde anne ve çocuk sağlığı konusunda aileleri takip etmesi (ev ziyaretleri, rutin aramalar, tutulan kayıtlar) biyo-iktidarın gözetim teknikleri ile açıklanmaktadır. İktidar tekniklerinin ve gözetim stratejilerinin beden üzerinden nasıl işlediğini tartsşan Foucault’ya göre (2007) bu sürecin etkili hale gelmesi için aynı zamanda iktidarın kullandığı yöntemlerin de dönüşüme uğraması gerekmektedir. Nitekim benlik teknolojilerine yönelik geliştirdiği çözümleme iktidarın hem makro hem de mikro fiziğinin nasıl değiştiğini anlamamızı sağlar (Foucault, 2007; Gutman ve ark. 1999). Bireylere bedeni ve sağlı̆̆ını kendi imkânları veya başkalarının yardımıyla dönüştürme imkânı veren bu iktidar anlayışı, baskı ve zorlamayı içermeyen çeşitli teknolojiler yardımıyla dolaylı işleyen etkili bir yöntem olarak görülmektedir. Planlı emzirme programlarının (bireysel farklılıklar, sosyal koşullar çoğu zaman göz ardı edilerek) uygulanması, uzmanların sunduğu tavsiyelerin uygulamaya konulması, emzirme danışmanlığının ortaya çıkması ve kadınların artan oranda danışmanlık talep etmesi, süt artırmaya yönelik verilen her türlü gıda ve takviyenin tüketilmesi, gündelik faaliyetlerinin ve kamusal ilişkilerinin (iş gücüne katılım, esnek çalışma, ücretsiz izin) bebek beslenmesine ve bakımına göre ayarlanması, herhangi bir baskı ve zorlama içermeden annelerin bedeni ve sosyal yaşamı üzerinde işleyen dolaylı iktidar biçimlerini ifade eder.

Halk sağlığı çalışmalarına paralel olarak gönüllü kuruluşlar da emzirmeyi teşvik edici girişimler başlatmış ve hükümetlerle iş birliği geliştirmiştir. 1960'ların sonlarında, formül endüstrisinin baskınlığına ve bebek beslenmesinin tıbbileşmesine meydan okuyan doğal sağlık hareketinin çalışması sonucunda emzirmede bir canlanma görülmüş ve Kuzey Amerika ve Avrupa'daki bu emzirmenin canlanması, La Leche Ligi gibi annelerin liderliğinden oluşan grupların aktivizmi yoluyla gerçekleştiği tartışılmıştır. La Leche League (LLL) kâr amacı gütmeyen, gönüllülerden oluşan ve 
emzirmek isteyen kadınlara eğitim, destek ve bilgi sunmak adına 1956 yılında kurulmuş olan bir oluşumdur. Doğal doğumu da destekleyen bu kuruluş, özellikle formül mamalara karşı çıkarak anne-çocuk arasında bağı önemsemekte ve emzirmenin de bu bağlamda önemini vurgulamaktadır. Anneden anneye destek, cesaretlendirme, bilgilendirme ve eğitim sağlayarak emzirmeyi teşvik etmekte olan uluslararası bir organizasyon haline gelmiştir (Ward, 2000; Wiessinger ve ark., 2010). Türkiye'de de gönüllü hizmet veren bu kuruluş, emzirmeye ilişkin bilgi ve destek hizmetlerini bilimsel söylemlerle çerçevelemekte, çoğu yerde yerel sağlık politikaları ile iş birliği içinde faaliyet göstermektedir. Dünya üzerinde 75 'ten fazla ülkede hem yerel hem uluslararası düzeyde faaliyet gösteren ve dijital medyayı da kullanarak emzirmek isteyen kadınlara ulaşmaya çalışan Leche League International'a göre, emzirme bebeğin ihtiyaçlarını anlamanın ve tatmin etmenin en doğal ve etkili yoludur (https://www.llli.org/wpcontent/uploads/Annual-Report-FYE-2019.pdf). Emzirmenin halk sağlığı sorununa entegre edilerek yerel ve uluslararası düzeyde politikleşmesini sağlayan bir diğer adım ise Dünya Sağlık Örgütü ve UNICEF'in ortak bildirisine dayanan "başarılı emzirmede 10 adım" ${ }^{3}$ kriterlerinin uygulayan hastanelere "bebek dostu hastane" unvanın verilmesidir (Lee, 2007, s. 1078; http://www.ttb.org.tr/STED/sted1000/8.html). Türkiye'de de 1991 yılından bu yana “Anne Sütünün Teşviki ve Bebek Dostu Sağlık Kuruluşları" programı emzirmenin korunması ve desteklenmesi amacıyla yürütülmekte olup, Dünya Sağlık Örgütü ve UNICEF tarafından önerilen "10 adım ilkesi" uygulanmaya çalışılmaktadır. Emzirmenin bebek beslenmesi içindeki önemine dikkat çekmek için “ANNE SÜTÜ BİR HAZINEDİR” sloganı ile anne sütü sağma broşürü, "ANNELER BEBEĞINIZ İÇİN EN IYİ BESIN ANNE SÜTÜDÜR" teması ile bir sayfalık görsel, "BAŞARILI EMZIRMENIN 10 ADIMI" başlıklı poster (Dünya Sağlık Örgütü, UNICEF ve Sağlık Bakanlığı Logosu ile basılmış) hazırlanarak sağlık kuruluşlarına dağıtımları ve sergilenmesi sağlanmıştır. ${ }^{4}$ Küresel ölçekte faaliyet

3 1. Kuruluşta çalışan tüm sağlık görevlilerine düzenli olarak iletilen, yazılı bir emzirme politikası oluşturmak.

2. Bu politikayı yürütmek için gerekli becerileri tüm sağlık görevlilerine kazandırmak üzere bir eğitim programı hazırlamak.

3. Tüm hamile kadınları emzirmenin yararları ve uygulaması hakkında bilgilendirmek.

4. Annelere doğumdan sonraki ilk yarım saat içinde emzirmeye başlamaları için yardım etmek.

5. Annelere nasıl emzireceklerini göstermek bebeklerinden ayrı kalsalar da, emzirmeyi nasıl sürdürebileceklerini öğretmek.

6. Tıbbi bir gereksinme olmadıkça yeni doğana anne sütü dışında herhangi bir yiyecek ya da içecek vermemek.

7. Anne ve bebeğin 24 saat aynı odada kalmasını sağlamak (Rooming- in).

8. İsteğe bağlı emzirmeyi özendirmek.

9. Anne sütü ile beslenen bebeklere biberon veya yalanc1 emzik vermemek.

10. Anneleri, taburcu olduktan sonra da emzirmeye devam edebilmeleri (bkz. Özsoy; Aksu, 2019)

4 Görsellere ulaşmak ve ayrıntılı bilgi için bakınız: https://hsgm.saglik.gov.tr/depo/birimler/cocuk_ergen_db/ dokumanlar/yayinlar/afis_brosur/Anne_Sutu_Afis.pdf

https://hsgm.saglik.gov.tr/depo/birimler/cocuk_ergen_db/dokumanlar/yayinlar/afis_brosur/St_ sama_07_02_2020.pdf

https://hsgm.saglik.gov.tr/depo/birimler/cocuk_ergen_db/dokumanlar/yayinlar/afis_brosur/Anne_Sutu_ Brosur.pdf

https://hsgm.saglik.gov.tr/depo/birimler/cocuk_ergen_db/dokumanlar/yayinlar/afis_brosur/DEV_POSTER_PDF_baar_emzirmede_10_adm.pdf 
gösteren uluslararası örgütler, hükümetler ve yerel kurumlar iş birliği içinde emzirme sürecine ilişkin faaliyetleri, eylemleri ve politikaları organize ederek, sağlığa, bedene ve anneliğe ilişkin süreçleri de düzenlendiği söylenebilir. Hamilelik süreciyle başlayan ve sonraki aşamalarda çeşitli bilgi, eğitim, destek, teknik ve kontrolleri içeren bu emzirme teşvikleri, gündelik hayatın ritmini ve kadın bedenini düzenleyen bir proje olarak da okunabilir.

\section{Tartışma: Emzirmenin Ahlaki Bir Meseleye Dönüşmesi}

Kadının birincil görevinin çocuk doğurmak olduğu ve dolaysıyla onun bakımına ilişkin süreç ve görevleri üstlenmesi gerektiği bir toplumsal vazife olarak sunularak, geleneksel toplumsal cinsiyet bakış açısı pekiştirilmektedir (Dow, 2016; Lareau ve Weininger, 2008; Zhou, 2017). Bu bakış açısı beslenme ve emzirme konusunda anneler üzerinden baskılayıcı bir ideolojiye dönüşerek, "iyi" nin veya "olması gereken" in sınırlarını belirlemektedir. Çünkü bebekler için anne sütünün değeri hakkındaki halk sağlığı mesajlarına paralel olarak, emzirme giderek daha iyi bir anneliğin sembolü ve ölçüsü haline de gelmektedir (Stearns, 2009, s. 63). Kadınlar, emzirmenin ne olduğunu (doğal ve içgüdüsel bir süreç) ve bunu neden yapmaları gerektiğini (bebeklerinin iyiliği için) anlatan güç söylemlerine tabidir. Anneler, uzman tıbbi bilginin pasif alıcıları olarak görülürken, aynı zamanda optimal bebek besleme kararları almaları için onlara yoğun bir sorumluluk yüklenir (Lee, 2018, s. 34). Emzirmenin bebek bakımı ve beslenmesinde yegane seçenek olarak sunulması ve böylelikle bir tercih meselesine de dönüştürülmesi, kadınlar üzerinde baskılayıcı olabilmektedir. Nitekim Lee'nin tartıştığ 1 gibi (2018) emzirmeyi tek seçenek olarak tartışmak yerine, emzirmeyi isteyenler için gerekli desteği sağlamaya ve emzirmeye karş1 sistemik engellerin üstesinden gelmeye teşebbüs edilmeye odaklanılmalıdır. Çünkü günümüzde neo-liberal politikaların sonucu bedene ve sağlığa ilişkin davranışlar bireyselleştirildiği gibi, emzirme de öncelikle kadınların sorumluluğu olarak bireyselleştirilmektedir Toplumsal, politik ve ekonomik koşullar sağlanmaksızın kadınlara emzirmenin bir gereklilik ve ahlâki bir zorunluluk olduğu "iyi” ve "ideal" anne ideolojisi ile sunularak, sosyal düzen içinde çeşitli bölünmelere yol açan farklı değişkenler göz ardı edilir. Irksal, sınıfsal ve toplumsal cinsiyetin yarattığı hiyerarşik bölünmeler, farklı kadınlık kimlikleri göz ardı edilerek emzirmeye ilişkin söylemler oluşturulur. Wolf’ un (2010) iddia ettiği gibi, emzirme, tarafsız olmayan, ancak yoğun annelik ve tıbbi uzmanlığın belirli soyağaçlarını yansıtan, çocukların sağlığı için gerekli olarak inşa edilmiştir. Yapılan alan çalışmalarında dikkat çekici bir şekilde bir annenin ne kadar iyi olduğunun emzirip emzirmediği gibi kriterler ile ölçüldüğünün vurgusunun ön plana çıkmasıdır (Lee, 2007; Marshall ve ark., 2007; Murphy, 1999). Örneğin bir annenin, bebeğini formül mama ile beslemeye karar vermesi, kendisini, ihtiyaçlarını, tercihlerini veya rahatlığını bebeğinin refahının üzerinde tutan 'yoksun bir anne' olduğu suçlamasına maruz kalmasına neden olabilmektedir (Murphy, 1999, s. 187). Kadınlar için emzirme 
genellikle bebek sağliklı ve mutlu göründüğünde iyi annelik ile eşdeğer tutulmakta, ancak emzirilen bir bebek sik sik besleniyor, ancak kilo almiyorsa veya huzursuzsa anne "yetersiz", "başarısız” görülebilmektedir (Marshall ve ark., 2007). Murphy'nin (1999) hamileliğin son ayından başlayarak, 2 yıl boyunca farklı meslek gruplarından seçtiği 36 kadınla gerçekleştirdiği derinlemesine mülakatlardan hareketle; bebek mamalarının neden olduğu kuşkulara rağmen, hem bebek beslenmesinde formül mama kullanmayı, hem de emzirmeyi planlayan annelerin toplumun ahlaki üyeleri olarak nasıl imaj oluşturduklarını anlamaya yönelik yaptığı alan çalışmasına göre; bir kadının aldığ 1 beslenme kararı ne olursa olsun, kararının yaptırımsal "sapkınlık" suçuna karşı savunmasız olduğunu ve konuşmasını böyle bir suçlamayı yenmek için inşa ettiğini göstermektedir. Söz konusu çalışma, anneler tarafından bebekleri ve küçük çocukları adına yapılan gıda seçimleri ahlaki yargılamaları içerdiğini ve kadınların seçimlerinden dolayı sorumlu tutulduklarını göstermiştir. Çalışmada, doğum öncesi dönemde kadınların büyük çoğunluğu emzirme niyetinde olduklarını bildirirken, göreceli olarak az bir kısmı ilk ayın ötesinde emzirmeyi özel sürdürdüğü gözlemlenmiştir. Kadınların kararları üzerinde etki eden farklı dinamikler de tartışılmakta, özellikle, sağlık profesyonellerin tutumu, aile ilişkileri, etkileşim örüntüleri, finansal kaynakların ve kadının çalışma kararı emzirme veya formül mama tercihi üzerinde etkili olduğu ele alınmaktadır. Murphy'nin yaptığı bu çalışma bir kez daha göstermiştir ki, bebek beslenmesine yönelik süreçlerin kadınların sorumluluğuna bırakılarak ahlaki seçim yapmaya zorlanmaları ve bu seçimin arkasında yatan dinamiklerin görmezden gelinmesi, konuyu bütünsel bir şekilde görmemizi engellemektedir.

Murphy'a göre (2000) neoliberal toplumda "iyi”" annelik maliyeti ne olursa olsun, çocuğu için fiziksel ve psikolojik sonuçları en üst düzeye çıkarması üzerinden tanımlanmakta ve bireylerden riskleri en aza indirgemek konusunda uzman tavsiyesini göz önünde bulundurması beklenmektedir. Sağlık ve bebek beslenmesi konusunda çeşitli öneriler ve tavsiyeler ışığında seçim yapmak zorunda kalan anneler, toplumun ahlâki ve kültürel değerleri ışı̆̆ında da karar alma süreçlerini yönetmek zorunda kalmaktadır. Hem "bilimsel" hem de "iyi" annelik rasyonel ve bireysel seçimi önemseyen, kendine ilgi duyan ve kendini gerçekleştiren, öznelliğe değer veren neoliberal bir kültürel çerçeve içinde kodlanarak anlam kazanır (Carter ve ark., 2018, s. 5). Bu tartışmalara eklenmesi gereken önemli konulardan biri de hükümetlerin emzirme politikaları, sağlık profesyonellerinin rolü ve sağlanan destekleri ne olursa olsun emzirmenin kadının sorumluluğunda olan bir davranış modeli olarak sunulması ve emziren kadının "iyi" bir anne olarak müzakere edilmesidir (Alianmoghaddam ve ark., 2017, s. 7). Bu bakış açısı emzir(e)meyen kadının ise kötü anne olduğu mesajını içinde barındırarak, ahlâki yargılamaya neden olabilmektedir. Nitekim annelik konusunda temel çalışmalara sahip olan Fransız Düşünür E. Badinter' in konuya ilişkin çözümlemesi, kadınlara dayatılan çeşitli stratejilerin onların sosyal yaşamı, kadınlık kimliği ve kamusal ilişkileri üzerinde etkili olduğunu ortaya koymaktadır (Badinter, 
2011). "İyi", "ideal" anne olmanın bir formu olarak kabul edilen doğal annelik de, kadınlara kendini feda etmeyi gerektirebilecek "aşırı derecede annelik" kültürünün standartlarına uymaya çalışmayı dayatabilmekte ve bütün bunları yaparken kişisel uğraşlarını; kariyerini, cinsel yaşamını ve kadınlık kimliğini de korumak zorunda kalabilmektedir. Badinter, son yıllarda egemen bir ideolojiye dönüşen doğal annelik mitini, modern annelik kültürün doğalcı ideoloji tarafından tahakküm altına alınması olarak tanımlamakta ve bu ideolojinin yarattığı annelik idealinin standartlarına uymayanlarda aşırı suçluluk yaratabildiğini, kendini doğal olmayan suçlu bir anne olarak hissetmesine neden olabileceğini ifade etmektedir. Çünkü Badinter "doğal olanın "en iyisi" olduğu iddiasının, kadınlarl çocuk yetiştirme ve iç sorumluluğun birincil yükünü oтиzlamaya ikna etme çabalarında bir araya gelen bir dizi regresif ebeveynlik davranışını haklı çıkarmak" olduğunu söyleyerek konuya dair radikal bir çözümleme yapar (akt., Hewitt, 2013). Konuya ilişkin yapılan bu değerlendirmeler annelik ideali etrafında dayatılan standartların, stratejilerin ve normatif düzenlemelerin aşırı formlarının kadınlar üzerinde baskılayıcı bir niteliğe bürünebileceğini göstermektedir. Farklı değişkenler göz ardı edilerek emzirmenin dayatılması veya ısrarla savunulması kadınlar için kısıtlayıcı veya baskılayıcı bir duruma dönüşebilmektedir.

"Meme en iyisi” fikrinin dayattığı ahlaki baskının yanı sıra anne sütünün yararlarına yönelik bilimsel kanıtlar, mamalara yönelik sentetik alg1 ve sağlığın giderek önemli bir norma dönüşmesi ışığında anneler arası süt paylaşımı önemli bir mübadele alanına dönüşerek yeni ilişki formlarının da ortaya çıkmasını sağlamaktadır. Nitekim günümüzde sadece yakın aile üyesi değil aynı zamanda sosyal medya hesapları üzerinde kurulan yerel topluluklar ve farklı internet siteleri üzerinden süt bağışı yapılmakta, çeşitli hastalıklara iyi geldiği düşüncesi ile yetişkin insanlar tarafından bile talep edebilmektedir (Carter ve ark., 2018). Son y1llarda kanttları olmamakla birlikte anne sütünün kanser hastalığı üzerinde iyileştirici etkisi olduğuna inanılması sosyal medya üzerinden süt taleplerini artırmıştır. "merhaba ismim Banu Bursada' yım esim kanser tedavisi görüyor anne sütü arlyorum yardımcı olabilecek Bursa'da yaşayan annelerden allah rizasi icin yardım bekliyorum”, "iyi günler acil anne sütü lazım kanser hastası abim için" ş şeklinde yapılan paylaşımlar ve annelerin bu paylaşımlara verdiği destek, farklı dayanışma ağlarının ortaya çıkmasına işaret ederken, anne sütünün satışını da gündeme getirmektedir. Nitekim Türkiye'de kadınlara hitap eden bir ebeveynlik ve sosyal paylaşım platformunda "1 ay oldu doğum yapall, sütüm çoğalsın diye sağdım ve çok şükür bebeğimde toparlandl sütümde arttı, isteyene makul bi fiyata vereceğim. İstanbul avrupa yakasında oturuyorum $2 \mathrm{klz}$ annesiyim. Kötü alışkanlığım hiç yok. Sağllklı ve süt yapan yiyeceklerle besleniyorum. Illgilenenler yazsın.", "Merhaba arkadaşlar 1 litresi 50 dolardan anne sütü satiyorum. Isteyenler irtibat numarasini

5 Ayrıntılı yazışmalar için bkz. https://forum.mutlubebekleriz.com/d/93775-anne-s-t-arayanlar/6 
biraksin" ${ }^{6}$ şeklinde yapılan paylaşımlar tıbbi söylemin, popüler sağlık söylemi ile birleşerek anne sütünün kapitalist sistem içinde değişim değerine sahip bir meta olarak algılanmasına yol açmakta ve talep edilebilirliği artırmaktadır. İnsan sütü değişimi, bankacılı̆̆ı, paylaşımı ve insan sütünün bireyler veya ticari kuruluşlar tarafından satın alınabileceği veya satılabileceği pazarların ortaya çıkması; sütün insan bedeninden bağımsız bir meta gibi ele alınmasının yanı sıra, emzirmenin de anlamının değişmesine yol açmaktadır (Palmquist ve ark., 2019).

Andrews ve Knaak'ın (2013) emzirme oranlarının yüksek olduğu Norveç ve Kanada'da 60 anne ile yaptıkları nitel bir çalışmada, annelerin tıbbi söylemin etkisi altında emzirme davranışlarını organize ettikleri ayrıca emzirmeye ilişkin daha geniş bir bask1, rekabet, yarg1 ve gözetim kültürünün söz konusu olduğu ortaya konulmuştur. Emzirmeye ilişkin yaygın kültürel beklentiler, emzirme oranı üzerinde etkili olmakta ve kadınların annelik deneyimini şekillendirmektedir. Bu bağlamda sağlık uzmanlarının, baskın tıbbi söylemin meşrulaştırılmış ajanları olarak, kuralları oluşturma ve aynı zamanda bu kurallara uyumu izleme yetkisinin oldukça güçlü bir kurumsal temsilcisi olduğu söylenebilir. Kadınların öznellikleri, içinde bulundukları kültürel ve sosyal ortam, çocuk sayısı, ırk, sınıf ve çalışma durumu gibi değişkenler göz ardı edilerek halk sağlığı politikalarına dâhil edilir ve duyguları anonimleştirilir. Emzirme bu hali ile büyük ölçüde ahlâki hale getirilir ve tartışmalar, "doğru" seçimi yapmak için annelere yoğun bir baskı uygulayarak ikili terimlerle çerçevelenir (Lee, 2018, s. 17). Annelik kimliği gibi emzirme de heteronormatif bir düzenin parametreleri içinde ideolojik olarak inşa edilmekte ve beyaz, orta sınıf değerlerin hegemonyasını içermektedir (Wolf, 2010, s. 13). Nitekim Carter'ın yaptığ çalışma emzirmenin farklı toplumsal bağlamlar içinde değerlendirilerek incelenmesi gerektiğini göstermiştir. Carter'a göre (1996) sosyo-ekonomik düzeyi düşük gruplardaki kadınlar için uzun süreli ve düzenli emzirmenin sağlıssı çalışma koşulları, uygun aile ortamının olmaması ve yoğun çalışma saatlerinden dolayı zor olabilmektedir. Çocuklarını biberonla beslemelerinin, bu kadınlara yaşamları üzerinde bir miktar kontrol hissi sağladığını vurgulamaktadır. Bu bağlamda Carter'ın (1996, s. 104-105) aktardığına göre, mahremiyet eksikliği, güven kaybı, barınma koşullarının yetersiz oluşu, ve yetersiz maddi kaynaklar, kısıtlı hissetme, çocuk bakımında destek azlığı ve diğer sorumlulukları içeren sosyal bağlamların hepsi emzirme süreci üzerinde rol oynamaktadır. Dünya Sağlık Örgütü ve tıp profesyonelleri emzirmenin ve anne sütünün faydalarını yaygın bir şekilde teşvik ederken, kadınların emzirme uygulamaları biyoloji, kültürel bağlam ve bireysel deneyimlerle şekillenmektedir (Rudzik, 2015, s. 11). Nitekim konuya ilişkin tartı̧malar emzirmenin geniş bir perspektifte ele alınması ve farklı değişkenlerin baskılayıcı etkisinin göz ardı edilmemesi gerektiğini bir kere daha ortaya koymaktadır.

6 Ayrıntılı yazışmalar için bkz. https://www.anneysen.com/bebek/soru-cevap/emzirme-sut-anne-ariyorum _41652; https://www.anneysen.com/bebek/soru-cevap/bebek-beslenmesi-anne-sutu-satisi-20180628_ 70241 


\section{Sonuç Yerine}

Çocuk sahibi olmanın kadınlığın önemli bir göstergesi olduğu düşüncesi, anneliğin içgüdüsel olduğu fikri ile birleşerek, genelgeçer bir annelik ve emzirme tanımlanmasına neden olmaktadır. Anneliğin doğal ve içgüdüsel bir durum olduğuna ilişkin yürütülen tartışmalar emzirmede de karşımız çıkmakta; emzirme hem kültürel hem de biyolojik olarak doğal anneliği temsil eden bir olgu olarak görülmektedir. Toplumun yeniden üretim işlevi içinde önemli bir role sahip olan kadınlar, annelik kimliği üzerinden hem politik hem de toplumsal bir özneye dönüştürülmekte ve çeşitli güç söylemlerine tabi kılındığ görülmektedir. Hamilelik, doğum, beslenme ve çocuğun bakım süreci toplumsal cinsiyetin normatif düzeni içine yerleştirilerek tıbbi, kültürel, ekonomik ve politik olarak inşa edilmektedir. Dolayısıyla bir yandan emzirmeyi doğal anneliğin önemli unsuru olarak kodlayan söylemler, öte yandan anneliğe ilişkin ürün, hizmet, süreç ve doğal durumların kapitalizme entegre edilerek bir tüketim alanına dönüştürülmesi birbiri ile çatışan farklı söylemlerin varlığına da işaret etmektedir. Çünkü hazır beslenme ürünlerinin ve mamaların önemli bir pazar payına sahip olduğu günümüzde emzirme, aynı zamanda doğal içgüdüsel bir davranış olarak egemen annelik ideolojisine entegre edilmekte ve neoliberal risk kültürü içine yerleştirilerek halk sağlığı söylemlerinde merkezi bir yer işgal etmektedir. Foucault'çu bir perspektifle konuya bakıldığında sağlıklı nesillerin teminatı için anneliğin yönetimselliği sağlanmakta ve kadın bedeni bir dizi gözetim ve iktidar stratejilerine biyoiktidara tabi kılınmaktadır.

"Meme en iyisi” sloganı ile günümüzde emzirmenin önemi vurgulanırken, kadınlar üzerinde yaratılan baskı ve sorumluluk da artmaktadır. Emzirmenin doğal ve dolayısıyla anne-çocuk için en iyi seçenek olduğu fikri, emzirmede zorluk çeken kadınların kendilerini “doğal olmayan” veya başarısız anneler olarak algılayabilecekleri riskini doğurmaktadır. Bu bakış açısı günümüzde yaratılan ve çocuğun isteklerini öncelikli tutan yeni annelik ideolojisi olan "yoğun" annelikle (Hays, 1996), birleşerek, bütün yaşamsal süreçleri etkisi altına alabilmektedir Her durumda çocuğun istek ve arzularının merkezde olduğu, annenin asli görevinin bu istekleri yerine getirmesi ve dolayısıyla kendi ihtiyaçlarını bastırması gerektiği hegemonik olarak işlemektedir. Bebek beslenme pratiklerinde de karşımıza çıkan bu bakış açısı iyi emzirmeyen veya emzir(e)meyen "kusurlu" bedenler yaratabilmektedir. Böylelikle "iyi", "yoğun" ve "ideal" anne aynı zamanda bebeği her istediğinde emziren, onun beslenmesinde en iyi besinleri düşünen ve dolayısıyla onun isteklerini öncellikli tutan anne olarak tanımlanmakta ve bu yeni formda "kendini adayan anne" ön plana çıkarak, aynı zamanda annelik ve ona içkin olan süreçler bir performansa dönüşmektedir. Emzirme ve beslenmeye ilişkin süreçler de bu performansın ne kadar etkin biçimde yerine getirildiği üzerinden tanımlanarak, toplumsal ve kültürel bakış açısı şekillenmektedir. Nitekim kadınlara özgü farklılıklar göz ardı edilerek (öznellik kapasiteleri, ,rk, sınıf, toplumsal cinsiyet gibi değişkenler), duyguları ve eylemleri politik ve ahlâki bir meseleye dönüştürülerek anonimleştirilmektedir. 
Bebek beslenmesi konusunda dikkat çekici noktalardan biri de hem emzirme meselesinde hem de hazır mamaların kullanımı ve pazarlanmasında tıbbi söylemin düzenleyici etkisinin egemen olmasıdır. Çünkü emzirme, saf, doğal ve sağlıklı olması bakımından tıbbi söylemlerle çerçevelenirken, bebek mamasının kapitalist sistem içindeki pazar payının korumasında ve sürdürmesinde tıp profesyonellerinin, doktorların ve hastanelerin tutumu etkilidir. Nitekim Lee'nin (2018, s. 34) belirttiği gibi bilimsel ve doğal anlayışlar genellikle karşıt olarak görülse de, birbirlerini çeşitli şekillerde pekiştirmişlerdir. Tıp, doğal ile yapay olanı bir karşıtlık ilişkisi içinde kurmak yerine, birbirini tamamlayan iki öğe olarak sunar ve her ikisi de kapitalist endüstri içinde önemli pazarların yaratılmasına aracılık eder. Bu bağlamda çalışmada çarpıcı olan tartışma; bebek beslenmesinde emzirmenin doğal, sağlıklı, güvenli ve "iyi” anne olmanın önemli bir göstereni olduğuna yönelik yapılan aşırı vurgunun da, emzirmeye ilişkin süreçlerin yeniden ve tersinden tüketim ilişkileri içine çekilmesine, ticari süreçlere dahil olmasına ve emzire(e)meyen kadınlar için baskıcı ahlaki bir forma neden olabileceğidir.

Hakem Değerlendirmesi: Dış bağımsız.

Çıkar Çatışması: Yazar çıkar çatışması bildirmemiştir.

Finansal Destek: Yazar bu çalışma için finansal destek almadığını beyan etmiştir.

Peer-review: Externally peer-reviewed.

Conflict of Interest: The author declares no potential conflicts of interest with respect to the research, authorship, and/or publication of this article.

Grant Support: The author received no financial support for the research, authorship, and/or publication of this article.

\section{Kaynakça/References}

Alburo-Caeñte, K. Z. K. (2014). Breast is best? A feminist re-reading of breastfeeding policies and practices in the Philippines. Philippine Quarterly of Culture and Society, 42, 115-137.

Alianmoghaddam, N., Phibbs, S., \& Benn, C. (2017). Resistance to breastfeeding: A Foucauldian analysis of breastfeeding support from health professionals. Women and Birth, 30(6), 281-291. https://dx.doi.org/10.1016/j.wombi.2017.05.005

Allan, J. (2004). Mother blaming: A covert practice in therapeutic intervention. Australian Social Work, 57(1), 57-70. https://dx.doi.org/10.1111/j.0312-407x.2003.00114.x

Andrews, T., \& Knaak, S. (2013). Medicalized mothering: experiences with breastfeeding in Canada and Norway. The Sociological Review, 61(1), 88-110. https://dx.doi.org/10.1111/1467-954x.12006

Apple, R. D. (1994). The medicalization of infant feeding in the United States and New Zealand: Two countries, one experience. Journal of Human Lactation, 10(1), 31-37. https://dx.doi. org/10.1177/089033449401000125

Badinter, E. (2011). Kadınlık mı? Annelik mi? (A. Ekmekci, çev.). İletişim Yayınları.

Blum, L. M. (1993). Mothers, babies, and breastfeeding in late capitalist America: The shifting contexts of feminist theory. Feminist Studies, 19(2), 290-311. https://dx.doi.org/10.2307/3178367

Boyd, C. (2011). The Nestlé infant formula controversy and a strange web of subsequent business scandals. Journal of Business Ethics, 106(3), 283-293. https://dx.doi.org/10.1007/s10551-011-0995-6 
Carter, P. (1996). Breast feeding and the social construction of heterosexuality or what breasts are really for. In J. Holland \& L. Adkins (Eds.), Sex, sensibility, and the gendered body. (pp. 99-119). Houndmills, UK: Macmillan.

Carter, S. K., Reyes-Foster, B. M., \& Carter, J. S. (2018). Breast is best, donor next: Peer breastmilk sharing in contemporary western motherhood. Sociological Inquiry, 88(4), 673-695. https:// dx.doi.org/10.1111/soin.12227

Cassidy, T. M., \& El Tom, A. (2015). Introduction: Ethnographies of breastfeeding: cultural contexts and confrontations. In T. M. Cassidy \& A. El Tom (Eds.), Ethnographies of breastfeeding (pp. 1-10). Bloomsbury Academic.

Conrad, P. (1992). Medicalization and social control. Annual Review of Sociology, 18, 209-232.

Cetin, H. (2019). Anne sütü satışı. https://www.anneysen.com/bebek/soru-cevap/bebek-beslenmesianne-sutu-satisi-20180628_70241

Crawford, B. S. (2010). History of motherhood: 1750 to 1900. In A. O’Reilly (Ed.), Encyclopedia of motherhood (pp. 500-504). Sage Publishing.

Demirtas, B. (2011). Türkiye'de anne sütü bankaları olmalı mı?. Anadolu Hemşirelik ve Sağlık Bilimleri Dergisi, 14(1), 73-77.

Douglas, S., \& Michaels, M. (2004). The mommy myth, the idealization of motherhood and how it has undermined women. Free Press.

Dow, D. M. (2016). Integrated motherhood: Beyond hegemonic ideologies of motherhood. Journal of Marriage and Family, 78, 180-196. https://dx.doi.org/10.1111/jomf.12264

Dykes, F. (2002). Western medicine and marketing: Construction of an inadequate milk syndrome in lactating women. Health Care for Women International, 23(5), 492-502. https://dx.doi. org/10.1080/073993302760190092

Ersoy, T. (2001). Tip ve yabancılaşma. Toplum Bilim, 13, 71-76.

Fomon, S. J. (2001). Infant feeding in the 20th century: Formula and beikost. The Journal of Nutrition, 131(2), 409-420. https://dx.doi.org/10.1093/jn/131.2.409s

Forcey, L. R. (1994). "Feminist Perspective on Mothering and Peace”. In E. N. Glenn, G. Chang, \& L. R. Forcey (Eds.), Mothering: Ideology, experience and agency (pp. 355-377). Routledge.

Foucault, M. (1993). Cinselliğin tarihi (H. Tufan, çev. ). Afa Yayınları.

Foucault, M. (2002). Kliniğin doğuşu (T. Keşoğlu, çev.). Doruk Yayınları.

Foucault, M.(2001). Toplumu savunmak gerekir (Ş. Aktaş, çev.). Yapı Kredi.

Foucault, M. (2007). İktidarın Gözü, Seçme Yazılar (4th ed.; F. Keskin, Ed.; I. Ergüden, çev.). Ayrıntı Yayınları.

Gida Güvenliği Hareketi (February 28, 2013). Diyanet'ten anne sütü bankası konusunda 2 ayrı yaklaşım. http://www.gidahareketi.org/Diyanet-ten-Anne-Sutu-Bankasi-Konusunda-2-AyriYaklasim-1669-haberi.aspx

Glenn, E. N. (1994). Social constructions of mothering: A thematic overview. In E. N. Glenn, G. Chang, \& L. R. Forcey (Eds.), Mothering: Ideology, experience and agency (pp 1-33). Routledge Company.

Gutman, H., Foucault, M., \& Hutton, P. H. (1999). Kendini bilme. (G. Ç. Güven, çev.). Om Yayınevi.

Haber7Com (March 27, 2013). Tepkiler üzerine geri adım. https://www.haber7.com/guncel/ haber/1006885-bakanlik-anne-sutu-bankasi-projesini-rafa-kaldirdi 
Happy Kids Forum. (July 2019). Anne sütü arayanlar. Retreived from https://forum.mutlubebekleriz. com/d/93775-anne-s-t-arayanlar/2

Hays, S. (1996). The cultural contradictions of motherhood. Yale University Press.

Henderson, A. C., Harmon, S. M., \& Houser, J. (2010). A new state of surveillance? An application of michel Foucault to modern motherhood. Surveillance \& Society, 7(3/4), 231-247

Hewitt R. (August 29, 2013). The conflict by Elisabeth Badinter-Review. The Guardian. https:// www.theguardian.com/books/2013/aug/29/womans-place-elisabeth-badinter-review

IMARC Group (n.d.). Baby Food and Infant Formula Market: Global Industry Trends, Share, Size, Growth, Opportunity and Forecast 2019-2024. https:/www.researchandmarkets.com/ reports/4763157/baby-food-and-infant-formula-market-global

Jung, C. (2015). Lactivism: How feminists and fundamentalists, hippies and yuppies, and physicians and politicians made breastfeeding big business and bad policy. Basic Books.

Kukla, R. (2006). Ethics and ideology in breastfeeding advocacy campaigns. Hypatia, 21(1),157-180. https://dx.doi.org/10.1111/j.1527-2001.2006.tb00970.x

Lareau, A., \& Weininger, E. B. (2008). Time, work, and family life: Reconceptualizing gendered time patterns through the case of children's organized activities. Sociological Forum, 23(3), https://dx.doi.org/10.1111/j.1573-7861.2008.00085.x

LeLeche League International. (2019). Annual report 2019. https://www.1lli.org/wp-content/uploads/ Annual-Report-FYE-2019.pdf

Lee, E. (2007). Health, morality, and infant feeding: British mothers' experiences of formula milk use in the early weeks. Sociology of Health \& Illness, 29(7),.1075-1090. https://dx.doi.org/10.1111/ j.1467-9566.2007.01020.x

Lee, R. (2017). Breastfeeding bodies: Intimacies at work. Gender. Work \& Organization, 25(1), 77-90. https://dx.doi.org/10.1111/gwao.12170

Lee, R. (2018). Ethics and politics of breastfeeding: Power, pleasure, poetics. University of Toronto Press.

Marshall, J. L., Godfrey, M., \& Renfrew, M. J. (2007). Being a "good mother”: Managing breastfeeding and merging identities. Social Science \& Medicine, 65(10), 2147-2159. https://dx.doi.org/10.1016/j. socscimed.2007.06.015

Moore, H. L. (2003). Mothering and social responsibilities in a cross-cultural perspective. In E. B. Silva (Ed.), Good enough mothering (pp. 58-75). Routledge.

Murphy, E. (1999). 'Breast is best': Infant feeding mecisions and maternal deviance. Sociology of Health \& illness, 21(2), 187-208.

Murphy, E. (2000). Risk, responsibility, and rhetoric in infant feeding. Journal of Contemporary Ethnography, 29(3). 291-325. https://dx.doi.org/10.1177/089124100129023927

Özsoy S., \& Aksu, H. (2019). Başarılı emzirmede on adım, 6. ve 9. adımların ihlali, nedenleri ve sonuçları. Türkiye Klinikleri Hemsirelik Bilimleri, 11(1), 74-80. https://dx.doi.org/10.5336/ nurses.2018-61845

Palmer, G. (2009). The Politics of breastfeeding: When breasts are bad for business. Martin Publishers.

Palmquist, A. (2015). Demedicalizing breastmilk: The discourses, practices, and identities of informal milk sharing. In T. M. Cassidy \& A. El Tom (Eds.), Ethnographies of breastfeeding. (pp. 23-21). London, UK: Bloomsbury Academic. 
Palmquist, A. E. L., Perrin, M. T., Cassar-Uhl, D., Gribble, K. D., Bond, A. B., \& Cassidy, T. (2019). Current trends in research on human milk exchange for infant feeding. Journal of Human Lactation, 35(3), 453-477. https://dx.doi.org/10.1177/0890334419850820

Porter, M. (2010). History of motherhood: 1900 to present. In A. O'Reilly (Ed.), Encyclopedia of motherhood (pp. 504-508). Sage Publishing.

Pylypa, J. (1998). Power and bodily practice: Applying the work of foucault to an anthropology of the body. Arizona Anthropologist, 13, 21-36.

Radbill, S. (1981). Infant feeding through the ages. Clinical Pediatrics, 20(10), 613-621.

Riessman, C. K. (1983). Women and medicalization: A new perspective. Social Policy, 14(1), 3-18.

Republic of Turkey Ministry of Health (February 7, 2020). Süt sağma. https://hsgm.saglik.gov.tr/ depo/birimler/cocuk_ergen_db/dokumanlar/yayinlar/afis_brosur/St_sama_07_02_2020.pdf

Republıc of Turkey Minıstry of Health (n.d.). Anne sütü afis. https://hsgm.saglik.gov.tr/depo/birimler/ cocuk_ergen_db/dokumanlar/yayinlar/afis_brosur/Anne_Sutu_Afis.pdf

Republic of Turkey Ministry of Health (n.d.). Anne sütü bir hazinedir. https://hsgm.saglik.gov.tr/depo/ birimler/cocuk_ergen_db/dokumanlar/yayinlar/afis_brosur/Anne_Sutu_Brosur.pdf

Republic of Turkey Ministry of Health (n.d.). Başarlılı emzirmenin 10 adımı. https://hsgm.saglik. gov.tr/depo/birimler/cocuk_ergen_db/dokumanlar/yayinlar/afis_brosur/DEV_POSTER_PDF_ baar_emzirmede_10_adm.pdf

Rothman, B. K. (1994). Mothers and fathers: ideology in a patriarchal society. In E. N. Glenn, G. Chang, \& L. R. Forcey (Eds.), Mothering: Ideology, experience and agency. (pp 139-157). Routledge.

Rothman, B. K. (2000). Recreating motherhood. Rutgers University Press.

Rudzik A. E. F. (2015). The embodied experience of breastfeeding and the product/process dichotomy in São Paulo, Brazil. In T. M. Cassidy \& A. El Tom (Eds.), Ethnographies of breastfeeding (pp. 11-21). Bloomsbury Academic.

Silva, E. B. (Ed.) (2003). Introduction. In Good enough mothering (pp. 1-9). Routledge.

Stearns, C. (2009). The work of breastfeeding. Women's Studies Quarterly, 37(3/4), 63-80.

Stevens, E. E., Patrick, T. E., \& Pickler, R. (2009). A history of infant feeding. The Journal of Perinatal Education, 18(2), 32-39. https://dx.doi.org/10.1624/105812409X426314

Sürekli Tıp Eğitim Dergesi (2000). On soru on yanıt. http://www.ttb.org.tr/STED/sted1000/8.html

Şişman, N. (2014). Sütün metalaşması: Biyomedikal/biyoetik yaklaşımlar. Sağlık Düşüncesi ve Tıp Kültürü Dergisi, 29, 40-43.

Tepehanım (2013). Sütü fazla olan anne arlyorum. https://www.anneysen.com/bebek/soru-cevap/ emzirme-sut-anne-ariyorum_41652

Thurer, S. L. (1994). Myths of motherhood. Houghton Mifflin.

Trevino, M. B. (2010). History of motherhood: 2000 b.c.e. to 1000 c.e. In A. O'Reilly (Ed.), Encyclopedia of motherhood (pp. 488-492). Sage Publishing.

Uzogara, E. E. (2015). Perceptions of motherhood: Differences among racial majority and minority women. International Journal of Culture and History, 1(1), 67-70, https://dx.doi.org/10.18178/ ijch.2015.1.1.012

Van Esterik, P. (1996). Expressing ourselves: Breast pumps. Journal of Human Lactation, 12(4), 273-274. 
Van Esterik, P. (2013). The politics of breastfeeding: An advocacy update. In C. Counihan \& P. Van Esterik (Eds.), Food and culture: A reader (pp. 510-530). Routledge.

Vancour, M. L. (2010). Breastfeeding. In A. O’Reilly (Ed.), Encyclopedia of motherhood (pp.142144). Newbury Park, CA: Sage Publishing

Varol, M. (February 27, 2013). Diyanet’ten 'anne sütü bankası' açıklaması. Hürriyet. https://www. hurriyet.com.tr/gundem/diyanetten-anne-sutu-bankasi-aciklamasi-22691568

Walks, M. (2010). Anthropology of mothering. In A. O'Reilly (Ed.), Encyclopedia of motherhood (pp. 63-67). Sage Publishing.

Wallace, L. E., \& Chason, H. (2007). Infant feeding in the modern world: Medicalization and the maternal body. Sociological Spectrum, 27(4), 405-438. https://dx.doi.org/10.1080/02732170 701335046

Ward, J. D. (2000). La Leche League: At the crossroads of medicine, feminism, and religion. University of North Carolina Press.

Wiessinger, D., West, D. L., \& Pitman, T. (2010). The womanly art of breastfeeding. Random House Digital.

Wolf, J. H. (2003). Low breastfeeding rates and public health in the United States. American Journal of Public Health, 93(12). 2000-2010. https://dx.doi.org/10.2105/ajph.93.12.2000

World Health Organization (2016). Breastfeeding in the 21. Century. https://www.who.int/pmnch/ media/news/2016/breastfeeding_brief.pdf

Zhou, M. (2017). Motherhood, employment, and the dynamics of women's gender attitudes. Gender \& Society, 31(6), 751-776. https://dx.doi.org/10.1177/0891243217732320

Zola, I. K. (1972). Medicine as an institution of social control. The Sociological Review, 20(4), 487-504. https://dx.doi.org/10.1111/j.1467-954x.1972.tb00220.x 